\title{
SIFTING THROUGH INFORMATION, LOOKING FOR PATHWAYS INTO CANADA'S LABOUR MARKET: \\ EXAMINING THE POTENTIAL OF LABOUR MARKET INFORMATION TO SUPPORT NEWCOMER/IMMIGRANT JOB HUNTING
}

By

Supriya Angela Latchman, Hons. BA Work and Labour Studies, York University, 2012

\author{
A Major Research Paper \\ Presented to Ryerson University \\ in partial fulfillment of the requirements for the degree of \\ Master of Arts \\ In the Program of \\ Immigration and Settlement Studies
}

Toronto, Ontario, Canada, 2014

(C) Supriya Angela Latchman 2014 
I hereby declare that I am the sole author of this Major Research Paper. This is a true copy of the MRP, including any required final revisions, as accepted by my examiners.

I authorize Ryerson University to lend this MRP to other institutions or individuals for the purpose of scholarly research.

I further authorize Ryerson University to reproduce this MRP by photocopying or by other means, in total or in part, at the request of other institutions or individuals for the purpose of scholarly research.

I understand that my MRP may be made electronically available to the public.

Supriya Angela Latchman 


\title{
SIFTING THROUGH INFORMATION, LOOKING FOR PATHWAYS INTO CANADA'S LABOUR MARKET: EXAMINING THE POTENTIAL OF LABOUR MARKET INFORMATION TO SUPPORT NEWCOMER/IMMIGRANT JOB HUNTING
}

(C) Supriya Angela Latchman, 2014

Master of Arts

Immigration and Settlement Studies

Ryerson University

\begin{abstract}
Labour market research consistently demonstrates that finding and securing appropriate employment are key determinants of immigrant well-being and integration to Canada. Various policyoriented initiatives are continually initiated by Canada's 'Third sector' actors to address multiple barriers immigrants confront in the labour market. While awaiting progress, the difficulties recent immigrants face in Canada's increasingly competitive local labour markets has increased. This amplifies the need for reexamining early interventions. This paper explores what and how labour market information (LMI) is mediated to recent immigrants at the earliest stages of settlement, and through a qualitative content analysis assesses how the LMI can inform and support labour market decisions of recent immigrants seeking employment in Canada. Findings uncover overwhelming amounts and varied quality of LMI available from Canada's labour force development providers. This leaves recent immigrants unable to independently make realistic, informative and suitable employment choices needed to integrate in the Canadian labour market.
\end{abstract}

Keywords: Recent immigrants, Labour market information; Labour force development; Labour market integration 


\section{Acknowledgements}

This major research paper is dedicated to immigrants and other marginalized job seekers contending with daily difficulties of finding and securing work in Canada's increasingly competitive and rapidly changing labour market. As well as, the immigration, settlement, and employment practitioners in the Employment Ontario Network, who work tirelessly on the front-lines to support and guide the job seeking process of newcomers.

This research would not be possible without the personal support and guidance of many. First and foremost, a sincere thanks for the unconditional support from my spiritual guru, dear parents, beloved partner, and many friends. Second, a sincere thanks to all my academic, community and professional mentors. I am particularly grateful for all the academic advisement Dr. Myer Siemiatycki provided from the onset of my ISS studies, Dr. John Shields, for his time, dedication to supervise this paper and provide encouraging feedback, and Dr. Bryan Evans, for agreeing to serve as my second reader without hesitation. Lastly, I am forever grateful for the continued guidance and opportunity to gain hands-on knowledge and experience concerning local workforce development issues, namely local labour market information

design and delivery from my community mentor, Karen Lior, Executive Director, Toronto Workforce Innovation Group and my colleagues, Luba Berezina and Enriketa Dushi. 


\section{TABLE OF CONTENTS}

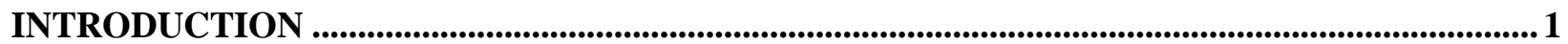

1. LITERATURE REVIEW AND THEORETICAL FRAMEWORK ...........................................3

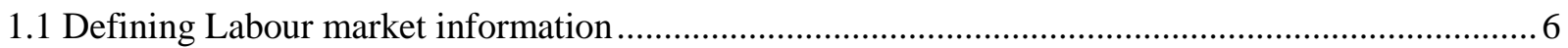

1.2.Canada's labour force development framework: LMI provision.................................................... 7

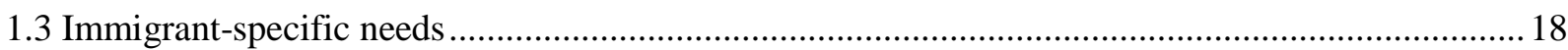

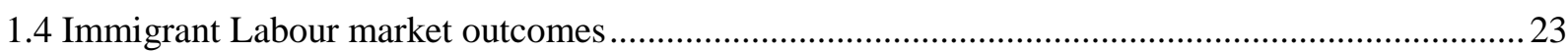

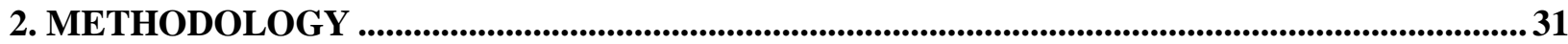

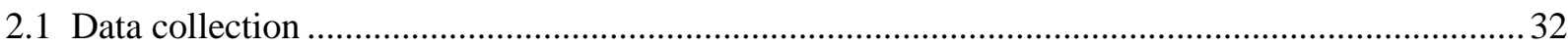

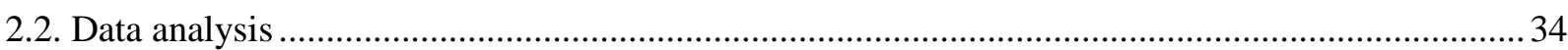

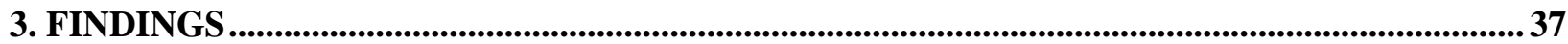

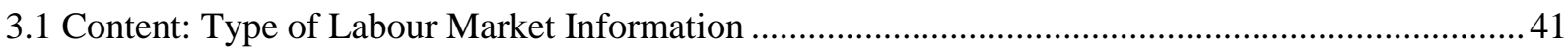

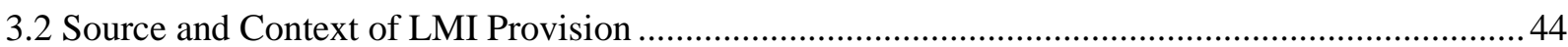

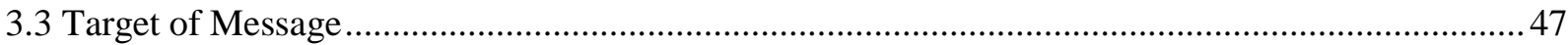

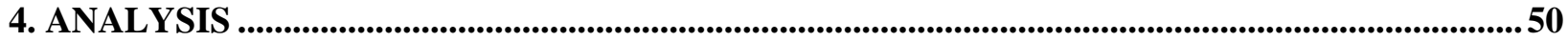

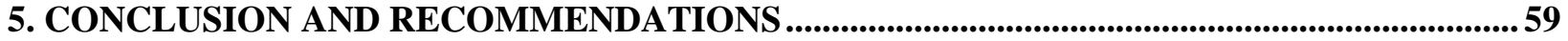

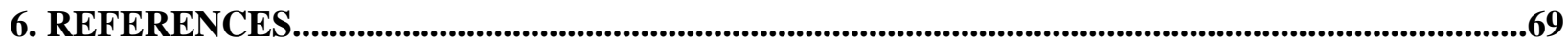




\section{LIST OF TABLES}

Table 1. Population of Immigrant Mother tongue families, showing main languages comprising each family, Canada, 2011 ....................................................................................................................21

Table 2. Unemployment and Participation rate for immigrants by Educational Attainment and 10 selected countries of Brith, Toronto CMA.............................................................26

Table 3. Average Hourly wage (2005 dollars) for Canadian-born and Immigrants

by period of Immigration and Sources of Information for finding current job, Canada....... 30

Table 4. Pre-arrival LMI provision for newcomers from 11 selected online sources....................... 39

Table 5. Post-arrival LMI provision for newcomers from 14 selected sources............................... 40 


\section{LIST OF CHARTS}

Chart 1. Proportion of Individuals by Immigrant Status employed in Entry -level job categories ........28 


\section{LIST OF FIGURES}

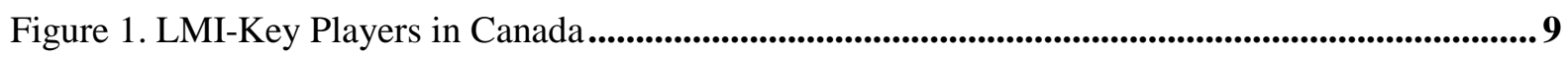

Figure 2. Sample-Life Course of an Adult Immigrant with Family ........................................................12

Figure 3. Job Search Model for Skilled Immigrants ......................................................................................... 18

Figure 4. Unemployment rate by Immigration class 6 months, 2 years and 4 years after landing in Canada ....................................................................................................24

Figure 5. Full-time Employment by Immigration Class, 4 years after landing, Canada ........................25

Figure 6. Average Hourly Wage (2005 dollars) by Immigration Class, 2 years and 4 years

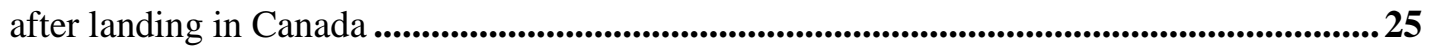

Figure 7. Reason for not checking credentials ** by regulated occupations and gender, Canada ........30

Figure 8. A Model of Factors that May Influence Information Access and Use by Newcomers......... 35 


\section{LIST OF MAPS}

Map 1. 2013 Employment Concentration, City of Toronto ..........................................................16

Map 2. 2013 Employment Districts, City of Toronto .................................................................................17 


\section{LIST OF APPENDICES}

Appendix 1. Pre Arrival LMI Provison Sample .........................................................................................6 64

Appendix 2. Post Arrival LMI Provison Sample .............................................................................................6 65

Appendix 3. LMI Content Analysis Selective Coding Guide ...............................................................66 


\section{INTRODUCTION}

Upon arrival, recent immigrants contend with the harsh realities of finding stable employment with decent pay, safe working conditions and commensurate income-earning opportunities in the Canadian labour market. Many obtain jobs well below their qualifications as a means of survival, predominately in low wage service work (Galabuzi, 2006; Teelucksingh and Galabuzi, 2007). Contextual factors and changing processes within the Canadian labour market are attributed for the labour market integration issues experienced by contemporary waves of immigrants since 1980s (Reitz, 2007). This largely includes institutionalized and individualized discrimination embedded in immigration selection, employment and labour market policies/processes which prevent labour market access and mobility on the basis of one's ethnicity, race, gender and/or immigration status (Bauder, 2006; Reitz, 2007; Teelucksingh and Galabuzi, 2007). Many policy-oriented initiatives are continually undertaken on variety issues concerning immigrant labour market integration. Specific interventions often focus on addressing issues in foreign credential accreditation process; bridge-to-work programs; and improving service delivery coordination among stakeholders (Teelucksingh and Galabuzi, 2007). Despite ongoing efforts on immigrant labour market integration led by Canada's settlement sector (Stasiulus, Hughes, Amery, 2011; Biles et al., 2011), the necessary interventions may take years to engage relevant actors and implement at all levels of government.

For recent immigrants, immediate interventions are needed to help mitigate labour market barriers in job hunting process, especially in major urban cities, like Toronto. Although many recent immigrants are settling in the surrounding Greater Toronto Area, they are competing even more for any available employment opportunities concentrated in Toronto's downtown core along with young professionals and immigrants (City of Toronto, 2013; 2014; Tal and Enenajor, 2013). This is because availability of full-time stable employment in high-skilled knowledge based service work has 
significantly decreased while causal and informal employment has increased (TWIG, 2011; 2013). Evidently, poor outcomes among all three groups in Toronto's labour market have produced the highest unemployment rates since 2008-2009 economic recession (Tal and Enenajor, 2013). Despite organizational mandates to provide adequate job hunting information, services and supports, communitybased organizations serving immigrants and other populations have become increasingly constrained under limited and diminishing program funding (Richmond and Shields, 2004; TIEDI, 2012b). Additionally, reliance on ethnic ties and communities for alternative information and support to gain access, entry, and mobility in Canada's labour market has only reproduced existing racial/ethnic segregation pre-conditioned by Canada's immigration selection policies (Ooka and Wellman, 2003).

Labour market research consistently confirms that finding, securing, and sustaining appropriate employment [in the first four years] are key determinants of immigrant well-being and successful integration to Canada (Shields, Lo, Zikic and Atlin, 2011). Given the difficulties recent immigrants contend with in local labour markets, the need is amplified for re-examining early interventions. In doing so, we can ensure newcomers/recent immigrants are equipped with information, tips and tools that are needed to help mitigate labour market barriers.

One immediate intervention that remains under-examined pertains to provision of labour market information in the pre and initial post arrival stage. Few studies in labour and migration literature provide insight about how immigrants find employment or make use of employment information to secure work (George et. al, 2004 quoted in Caidi, Allard and Quirke 2010: 520). More recent public policy discussions on Canada's labour force development system indicates there is an absence of good, reliable, timely and accessible labour market information for all labour market participants, which includes immigrants (Advisory Panel on Labour Market Information, 2009; Drummond, 2014; Sharpe and Qiao, 2006). As a result of this information gap there are greater levels of confusion, unrealistic job seeking 
expectations and ineffective skills matching which is poorly matched to the needs of Canada's changing economy and labour markets (Drummond 2014; Criptoph, 2003). In the same respect, this situation fails to make good use of the foreign skills and experiences immigrants have (Galabuzi, 2006).

To further enlarge the informational perspective on immigrant labour market integration, this research paper will focus on examining what, where, and how recent immigrants can obtain adequate labour market information to better prepare, transition, and advance in the Canadian labour market. This paper provides an in-depth content analysis on pre and post arrival labour market information/resources in Toronto. The research findings will identify and assess how the quantity and quality of available labour market information can support recent immigrants during the job hunting process. Therein, adding new insight to better inform Canadian policy makers and practitioners on the appropriate interventions needed in the provision of labour market information, services and supports for newcomers/immigrants.

\section{LITERATURE REVIEW AND THEORETICAL FRAMEWORK}

As newcomers to Canada, recent immigrants generally seek out information, services and supports to assist the integration in major domains of life, which include: education system and language learning, employment, housing, health care, money and finances, the justice system, and cultural adaptation and community involvement (Esses and Medianu, 2012; Sharpe and Qiao, 2006). Despite the large number of government funded and community-based programs available, many recent immigrants still prefer seeking employment support from friends (36\% according to one survey) over settlement organizations (21\%) (Kunz 2005: 55).

Although little is known about how immigrants seek information and make use of it during job hunting (Caidi, Allard and Quirke, 2010), the stronger preference to utilize personal networks for employment support demonstrates recent immigrants are having difficulty seeking and utilizing 
community-based or government funded services to find employment. Therein suggesting information and service gaps exist in community-based and government funded employment programming. It is important to note this is notwithstanding other labour market barriers immigrants encounter from institutional process and polices administered by immigration selection, regulated industry bodies and employers (Bauder, 2006; Reitz, 2007; Galabuzi, 2006;Teelucksingh and Galabuzi, 2007).

Since labour market information remains an important lynchpin for career counselling, skills training, job matching services provided to labour market participants, it is important to understand all systemic factors linked to provision of employment information to ensure Canada's and more specifically, Toronto's labour force readiness (Criptoph 2003; Esses and Medianu, 2012; Sharpe and Qiao, 2006). This requires a holistic policy and practitioner based discussion on the systemic issues immigrants continue to confront when navigating Canada's complex labour force systems.

Throughout this literature review, I will be making distinct linkages between the structural processes of labour market information provision in Canada's labour force development framework, immigrant servicing needs and the impact on immigrant labour market integration. This paper draws employment, labour, immigration and settlement, and public policy/practitioner perspectives on labour market integration issues confronting various populations and their intersecting identities, ie. visible minorities, women, persons with disabilities, and aboriginals. In addition, I am drawing on my community-based perspectives on local labour market programming in Toronto's Employment Ontario network. Together these perspectives explain how labour market information in Canada's labour force development framework can be complex and difficult for both immigrants and immigrant service providers to access and utilize in Toronto's changing labour market. As well, this review uncovers specific information provision inadequacies which shape the type of career counselling, skills training and 
job matching services, and subsequently the outcome of immigrant labour market integration in the Canadian workforce.

The perspectives which guides this study are consistent with social inclusion principals articulated by Omidvar and Richmond (2003) and enlarged from an informational perspective by Caidi and Allard (2005) and Caidi, Allard and Quirke (2010). These perspectives contend that for immigrant newcomers to successfully integrate in the labour market, information designed by Canadian public policies delivered in immigration and settlement and related programs need to cover the following dimensions ${ }^{1}$ :

- Valued recognition- The [labour market] information recognizes the intersection difference among immigrants, as non-homogenous user group with multiple interesting identities, which include: race, class and gender;

- Human development- The [labour market] information relayed seeks to nurture talents, skills, capacities and commensurate choices of immigrants, who are job seeking to live a life they value and to make a contribution both they and others find worthwhile;

- Involvement and Engagement- The [labour market] information relayed and the medium/mechanisms used to relay it allows them the right and the necessary support to make/be involved in career laddering decision affection oneself, family and community;

- Proximity- The [labour market] information exchanged reduces social distance between immigrant job seekers and Canadian employers; and

- Material well-being- The [labour market] information supports and advances the economic integration of recent immigrants.

While these perspectives help critically unpack the systemic issues underpinning information servicing inefficiencies in community based and government employment programing, the discourses often situate recent immigrants, as passive victims who are disadvantaged in the Canadian market. Recognizing these discursive limitations of selected perspectives, I view recent immigrants, as one group of labour market participants, who do have some autonomy and capacity like other marginalized

\footnotetext{
${ }^{1}$ Social Inclusion/Exclusion dimensions in Information provision adopted from Caidi and Allard (2005:304) discussion on social inclusion as information problem in settlement service provision, which builds on Chatman's theory of information poverty $(1985,1987,1991)$.
} 
jobseekers to take control, identify, and actively make use of necessary formation available in job seeking. Likewise, community-based service providers can be seen as an important labour market information provider with individual and/or collective organizational capacities to collect, analyze and disseminate information needed to actively support newcomer/immigrant job hunting.

\subsection{Defining Labour market information}

Labour market information (LMI) varies in definition and usage. In the broadest sense, it is characterized by the Forum of Labour Market Ministers (FLMM) as "information needed to make a labour market decision" (Sharpe and Qiao, 2006). More specifically, LMI can provide different labour market agents with “...knowledge, facts, and relevant institutional information on the supply and demand of various different types of labour services (employment), including wages and other forms of compensation" (Advisory Panel on Labour Market Information, 2009: 3). Major uses of LMI can facilitate and support the decision making of different labour market agents (Advisory Panel on Labour Market Information, 2009; Sharpe and Qiao, 2006). This includes individual transactions undertaken by any labour market participant, like recent immigrants (Advisory Panel on Labour Market Information, 2009). As well as, policy-based or marketplace decisions/processes undertaken by labour market stakeholders, i.e., all levels of governments, businesses, other private sector/industry bodies, organized labour, non-for-profit sector, and colleges, universities and other training and education bodies (ibid). LMI can inform all labour market agents on career opportunities, job prospects, labour market conditions and projections (past, present or future), education and training opportunities, human resource needs, and the impact of program/policy changes (ibid). LMI can be accessed in-person and/or online in oral or written form through a number of formal or informal mediums.

An effective LMI system should consider the intersecting/unique needs of diverse worker groups,

e.g. "...preference to oral patterns, particularly among low-income people, in order to reduce the 
information gap" (Sharpe and Qiao, 2006: 59). These concerns are frequently raised by Canada's settlement sector who explain, “...[recent] immigrants require good, solid information to realistically assess their prospects, especially considering the risks undertaken to move from their familiar home country to a foreign land with a very different labour market" (Advisory Panel on Labour Market Information, 2009: 6). Information on occupations and skills that are needed in various cities and regions across the country and employment prospects in their field prior to arrival can reduce labour market barriers faced with upon arrival (ibid). In fact, immigrant women of colour, who have the worst outcomes in labor force integration, can benefit the most from LMI that is broken down by gender. This can help them understand the specific conditions of work beyond compensation, including information on flex time, and time off for family responsibilities such as child care and elder care (ibid, iv-v).

The effective LMI system characterized here clearly advocates for a more worker-centered information provision model, which is missing and needed in the current labour force development system (Advisory Panel on Labour Market Information, 2009: 64). This does not discredit firm/industrycentered perspectives in LMI information provision model. However, more emphasis on collecting, interpreting, analyzing, and disseminating LMI to and for different worker groups is advised to ensure marketplace decisions/processes deployed by key labour market policy makers and practitioners maintain both economic development and labour force development interests of all parties (Advisory Panel on Labour Market Information, 2009; Drummond, 2014; Criptoph 2003; Esses and Medianu, 2012; Sharpe and Qiao, 2006).

\subsection{Canada's labour force development framework: LMI provision}

Public policy discussions on LMI provision reveals Canada has a well-developed yet, complex LMI system in need of significant improvements on behalf of the Federal government and other labour market stakeholders at a national, provincial and municipal level (Advisory Panel on Labour Market 
Information, 2009; Drummond, 2014; Criptoph, 2003; Esses and Medianu, 2012; Sharpe and Qiao, 2006). For recent immigrants and non-profit service providers, the fragmented, uncoordinated, outdated LMI provision does not facilitate clear access, making it very difficult to navigate. Nor is it conducive for informing and supporting labour market decisions in rapidly changing local labour markets.

The most in-depth LMI discussion was initiated in 2008 when the Forum of Labour Market Ministers (FLMM) commissioned an Advisory Panel on Labour Market Information (2009) to explore the provision of labour market information within Canada's labour force development system. Key findings reveal various issues and challenges around the collection, analysis and interpretation, and dissemination of LMI. The research and policy discourse does examine immigrants and immigration-specific stakeholders in broader labour force development discussion. However, an in-depth examination on the value, provision and utility of LMI to support newcomer integration in key domains including the labour market still remains under examined (Esses and Medianu, 2012; Caidi, Allard, Quirke, 2010). The lack of attention on immigrant labour market information issues and others reflect the types of LMI improvements undertaken and still needed as suggested by the Advisory Panel on Labour Market Information (Drummond, 2014). Specifically, around the better data collection for specific users and LMI coordination at local level where labour market decisions and processes take place and impact integration (Advisory Panel on Labour Market Information 2009; Drummond, 2014; TWIG, 2013: 30).

\section{i. Key players and nature of LMI provision}

There are number formal information intermediaries with varied capacities with regard to collecting analyzing and disseminating LMI. This has resulted in an overwhelming amount of information that is highly fragmented, uncoordinated, and difficult to find or utilize unless someone is able to carefully guide you (Advisory Panel on Labour Market Information, 2009: 80). There are six key players involved in Canada's LMI provision operating at national, provincial and/or municipal level (ibid:15-67). 
This includes the Government of Canada, Provinces/Territories, Private Sector and Sector councils, Federal/Provincial Partnerships, and Non-profit sector, see Figure 1. LMI-Key players in Canada. A closer examination on core public, private, non-profit providers highlights the complex and fragmented nature of LMI provision in Canada's current labour force development system.

\section{Figure 1. LMI-key players in Canada}

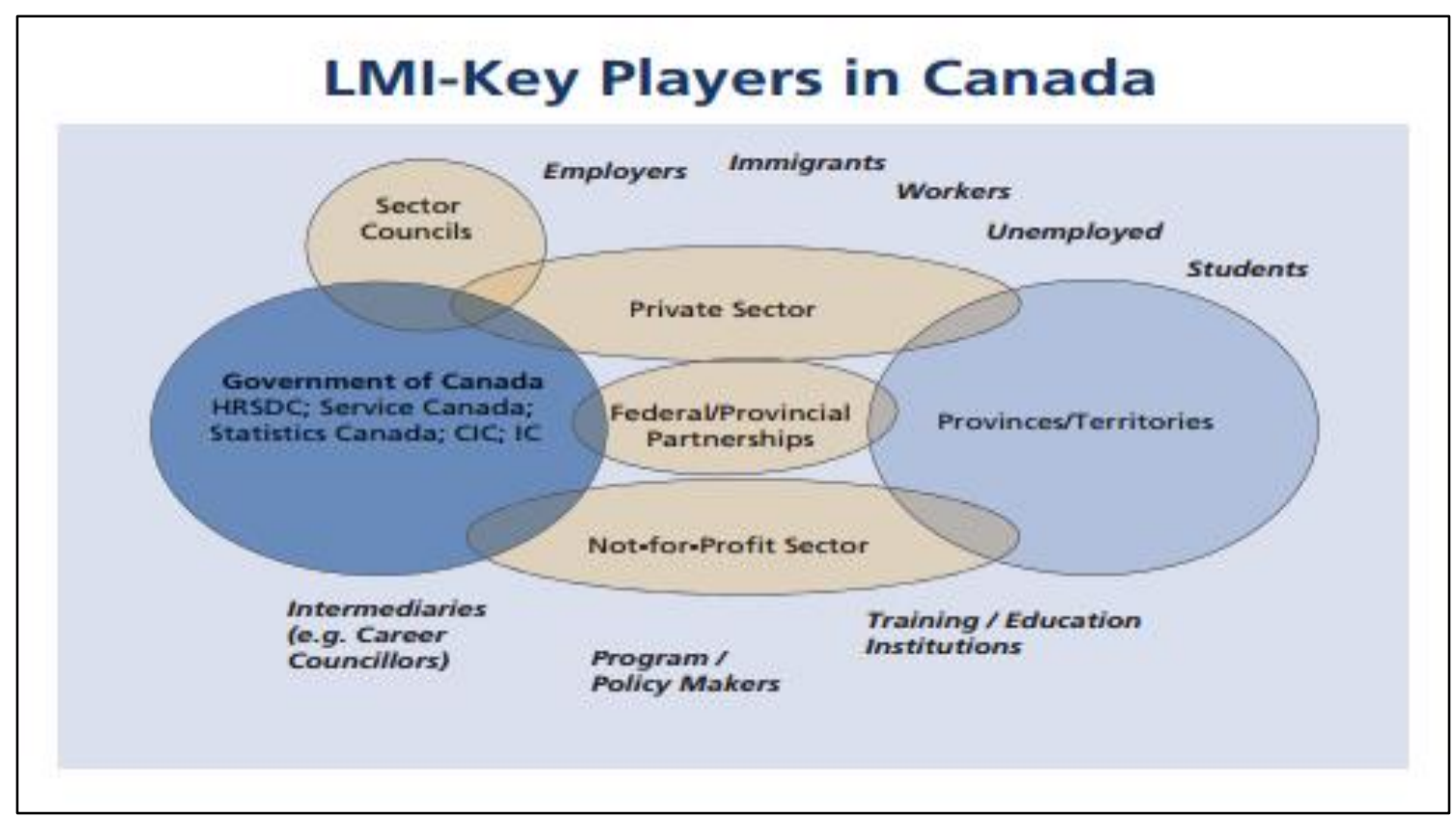

Source: Advisory Panel on Labour Market Information (2009:4)

The Government of Canada is the largest provider with four agencies at a federal and provincial level. This includes Human Resource and Development Canada (HRSDC), Service Canada, Statistics Canada, and Citizenship and Immigration Canada (CIC). Information from government tends to be highly statistical, with noticeable data gaps on specific job seeker groups and their intersecting needs. Even when it is made available for public use, the data is quickly outdated and requires time and resources to undertake quantitative analysis on labour market (TIEDI, 2012b). This is noted as growing concern among Toronto's non-profit actors, who are working under limited funding and resources to service various marginalized job seekers group, like immigrants (ibid). Only recently improvements to web-based 
technology and centralization of specific government agency tools, like Working in Canada have been undertaken on the main portal, Job bank.gc.ca (Drummond, 2014).

At a provincial level, the Ontario Ministry of Training, Colleges and Universities (MTCU) has lead responsibility with specific labour market information and research divisions conducting LMI research to address internal employment and training related policy issues (Advisory Panel on Labour Market Information, 2009:45-46). In general, there is lack of LMI on job vacancies and wages and this has contributed to confusion on the nature and magnitude of potential skills shortages (ibid). One distinguishing feature of Ontario's LMI system from other provinces/territories is the LMI provision from local workforce development boards (ibid, pp. 45-46, 64). These local labour force bodies were established in the early 1990s to replace Local Training Advisory Boards which were funded jointly by HRSDC and MTCU (ibid). Since implementation of the labour market development agreement in 2007, MTCU remains the lead sponsor (ibid). Local boards provide a range of reports including an annual local labour market report capturing workforce trends, opportunities and priorities from a worker-based perspective that does not exist anywhere else (ibid). In addition, they are involved in the design and delivery of local employment programs and services (ibid). Through my work with Toronto's workforce planning board, the Toronto Workforce Innovation Group (TWIG), there is generally a low level of awareness and utility of LMI provided by local workforce planning boards among jobseekers and service providers. This is mainly attributed to the larger pool of funding and policy engagement centralized among federal and provincial government and select universal service providers on Ontario's employment and settlement frameworks (Stasiulis, Hughes and Amery,2011; Biles et al, 2011).

Private sector providers include sector councils, headhunters and/or online labour exchange services ie. job aggregators, professional associations or unions and local businesses (Advisory Panel on Labour Market Information, 2009: 67). They provide a rich collection of industry specific information 
that exists at national, provincial and/or local level (ibid). Their direct ties to employers and industry bodies provides detailed occupational outlooks, and even links to available jobs or employers/workforce demographics (ibid). However, the analysis remains fragmented by industry, provinces and regions, which does not provide a holistic marketplace outlook. Additionally, LMI is often not accessible by members of the public but available to members in professional associations and government bodies. Overall, the gaps in private sector LMI provision should be complemented with other public LMI sources (ibid).

Non-profit sector providers include a range of community-based actors who provide basic and specific information, services and supports for all populations, which includes immigrants. Their role was overlooked in the Advisory Panel on Labour Market Information discussion (2009). Even more recently in Drummond's (2014) discussion which reasserted need for more localized LMI provision and coordination among Canada's labour force development actors. This is concerning as the practice of immigration and settlement policies and programs are largely an urban phenomenon delivered by civil society actors (Omidvar and Richmond, 2003), therein making localized settlement actors central to Canada's LMI system. In Ontario's immigration, integration and inclusion framework, Biles, Tolley, Andrew, Esses and Burstein (2011:229-234) explain various non-profit organizations design and delivery employment and settlement programs for immigrants and other populations. These include "universal" service providers, immigrant serving agencies (ISAs), multicultural NGOs, and issue based organizations. Universal service providers are the largest, most funded, and engaged non-profit organizations in settlement provision. They are typically national umbrella organizations that have been around for years to directly provide a broad range of services and/or to fund programs and initiatives by other nonprofit organizations (eg. YMCA, YWCA, United Way, Maytree Foundation, Learning Enrichment Foundation). ISAs are community-based organizations who provide direct services to immigrants' populations, broadly and/or more specifically on the basis of ethnicity, culture and/or faith. Multicultural NGOs are 
community-based organizations who provide a broad range of services for all populations. Many are established universal providers who have grown to service new immigrant populations in various neighborhoods (eg. COSTI). Issue-based organizations general focus on thematic or priority issues, which include women, health or employment (eg. Newcomer Women's Services, Access Alliance Multicultural Community Health Centre).

All non-profit service providers have similar but distinct service mandates on settlement and employment programming which varies in quality and quantity. Kunz (2005: 53) explains that immigrant and settlement programs should cater to distinct needs throughout major life-course stages of an Adult Immigrant with a family in Canada, see Figure 2. Based on my local labour market program knowledge in Toronto, there is a noticeable LMI servicing gap in the pre arrival stage compared to settlement and adaptation stage.

Figure 2. Sample Life-Course Transition of an Adult Immigrant with Family

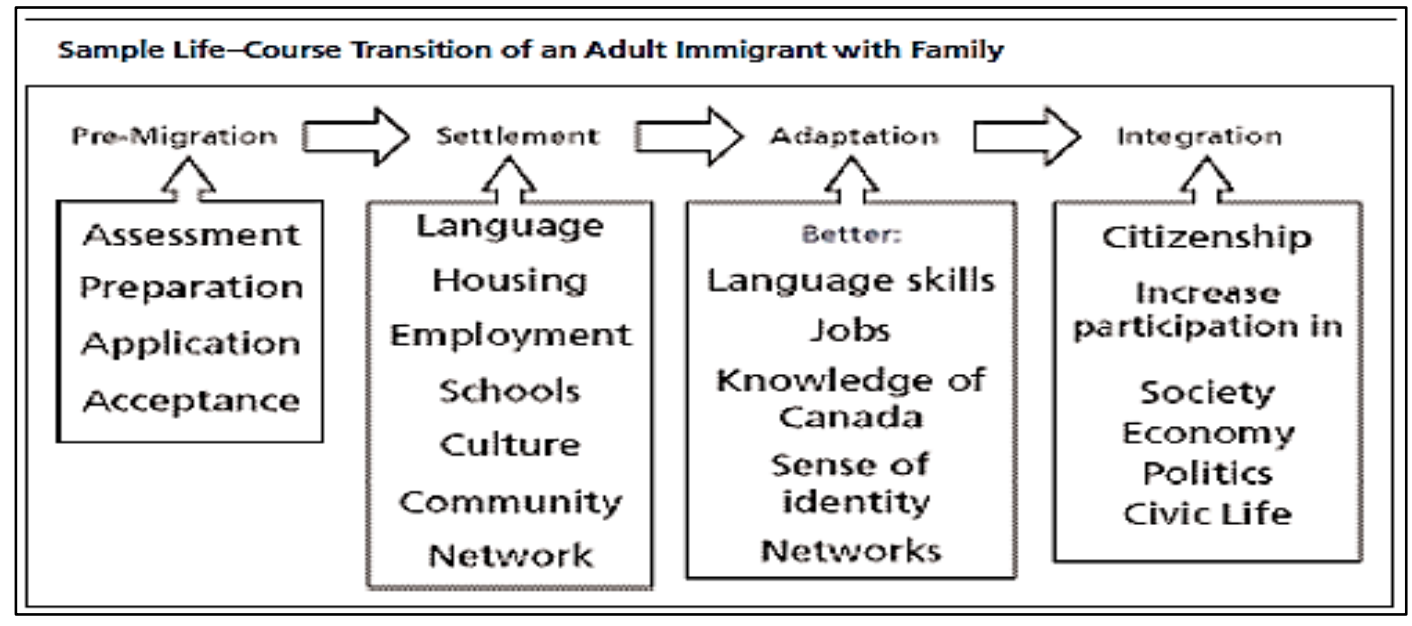

Source: Kunz (2005: 53)

For recent and prospective immigrants, the information, services and supports in the premigration and initial post arrival settlement stage are most crucial, particularly concerning language, housing and employment (Kunz, 2005). Only one pre-arrival LMI initiative exists, the Canadian 
Immigrant Integration Program (CIIP) Partners for Success (CIIP, 2014a). The program is funded by Citizenship and Immigration Canada and facilitated by Association of Canadian Community Colleges and "focal point partners", namely universal service providers, like COSTI. Since 2010, the program has served immigrants from countries including China, India, Philippines and approximately 69-73\% of immigrants were commensurately employed within one year of immigrating to Canada (Murphy, 2014). CIIP success has largely been attributed to "my map", a personalized career plan develop with a local job developer. Despite its success, awareness remains low with only 50\% of recent immigrants taking advantage of this initiative. This may be reflective of the disengagement among various non-profit service providers, especially smaller ISAs or NGOs, who have distinct employment and settlement programs to catering to specific/intersecting needs and ties to ethno-cultural communities that raise awareness. As well, there is not enough known about what regions, cities or towns within Ontario, British Columbia, Alberta and Manitoba benefit from this type of LMI (CIIP, 2014b).

Most post arrival employment and settlement programs, eg. ISAP, LINC and HOST are largely government-funded (Kunz, 2005), and delivered by primarily by non-profit service providers in Toronto and elsewhere in Canada outside Quebec. Many focus on a range basic employment programing, which includes resume writing. GIS mapping on immigration and settlement service provision across the Toronto and Greater Toronto area uncovered a low level of awareness, fragmented access to, and low satisfaction with settlement servicing, particularly among contemporary immigrant populations, ie. South Asian, West Asian and Caribbean populations (Lo, et al, 2007; 2010). The fragmented programming infrastructure has produced an inefficient model of service delivery that does not meet the unique and intersecting needs of immigrants (ibid). This is largely attributed to the limited and individualized contract funding framework settlement agencies are allocated (Richmond and Shields, 2004). On a similar but different note, unpublished research on utility of LMI in employment programming among Toronto's Employment Ontario service providers uncovered divergent practices when collecting and 
utilizing LMI in job development and career/employment counsellors (Occhiuto and Qunitero, 2012:12). Most providers consulted Federal LMI sources (80\%) and very few drew on non-profit sources (40\%), including TWIG's LMI or private LMI sources (20\%). This suggests that individual capacities, expertise and level of commitment to making use of LMI to support clients, also play a role in shaping labour market outcomes. In some attempts to address the inadequacies of local LMI provision, new LMI tools and online webinars, routestoemployment.ca and routestotrades.ca were created by TWIG and disseminated through local non-profit providers to centralize and support job seeking undertaken by recent immigrants in Toronto.

\section{ii. LMI provision systems gaps at a local level}

In addition to overlooking the central role of Canada's third sector in LMI provision, insufficient consideration about the nature and types of localized LMI already available from other formal and informal localized labour force actors was also overlooked in these policy-based discussions (Advisory Panel on Labour Market Information, 2009; Drummond, 2014). Specifically, the municipal governments and informal sources of information obtained through personal/social networks across various ethnic communities. Without fully recognizing how their roles work in conjunction formal LMI provision at a macro-scale, the efforts to begin improving coordinating and de-centralizing LMI at a local level will not be timely, accessible, and conducive for all job seekers, including immigrants.

Municipal governments are central actors in local labour force development. They design, deliver and fund a range of settlement and employment services with non-profit and private sector providers which operate at the national, provincial, and local level (Critoph, 2003). Among the services provided, LMI collected analyzed and disseminated helps to capture the make-up, changes in local economic development and its impact on the local labour force. LMI from the City of Toronto, Toronto's Workforce Planning Board (TWIG, 2013), and other formal localized labour market players consistently 
demonstrates "Toronto has not one but many labour markets" (Critoph, 2003:14), that are rapidly changing. This presents different workforce opportunities and challenges across twenty three employment districts (see Map 1 and 2). For recent immigrants, this information pre and post arrival may reduce confusion around what opportunities exist and clarify how foreign credentials, skills or experience can or cannot be utilized in the Canadian labour market. This needs to be considered by Canada's labour force development actors when undertaking labour market research, analysis and dissemination.

Addressing LMI provision from formal localized actors cannot fully solve the informational issues concerning immigrant labour market integration. There are multiple pathways and sources of obtaining labour market information, which recent immigrants mostly acquire overtime in a nonsystematic, informal manner (Caidi, Allard and Quirke, 2010). Non-traditional information intermediaries play a large role in mediating general or problem-specific information (eg. LMI) at a local and/or transnational level (Caidi, Allard, Quirke, 2010). Informal LMI provision usually comes from ethno-linguistic gatekeepers, community-based organizations and leaders who provide informal links between immigrant communities; and various information communication technologies (ICTs) which send and receive information transnationally (Caidi, Allard, Quirke, 2010: 507-509). These information practices are predominately undertaken among Asian diaspora (Kelly, 2003). Their informal role and impact in immigrant labour market integration is generally difficult to track and measure in social capital studies (Aizlewood and Pendakur, 2004; Ooka and Wellman, 2003). Yet it remains a prominent source of job seeking support compared to community-based settlement and employment programs (Kunz, 2005). 
Map 1. 2013 Employment Concentration, City of Toronto

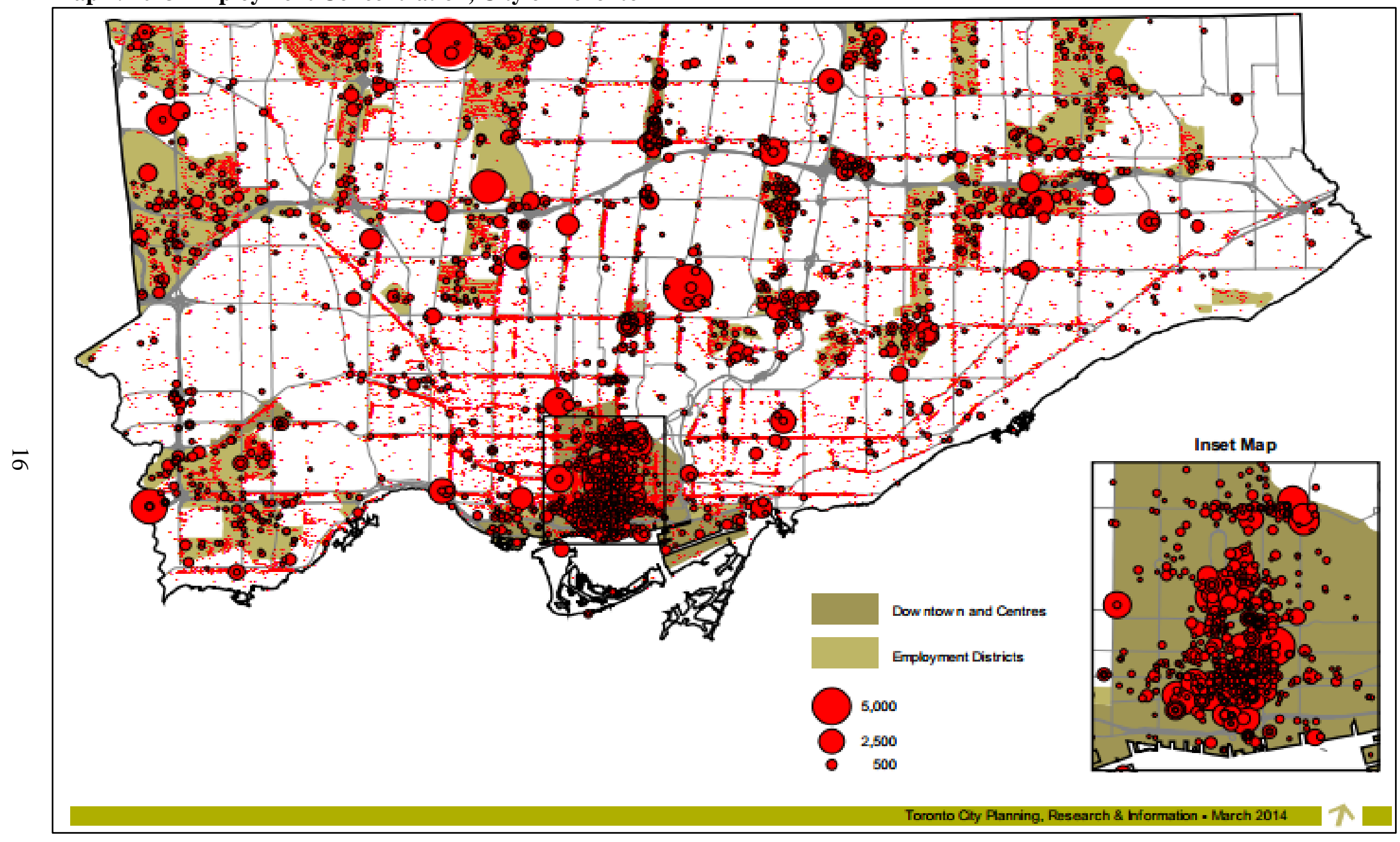

Source: Toronto Employment Survey, 2013, City of Toronto (2014: 3) 
Map 2. Employment Districts, City of Toronto

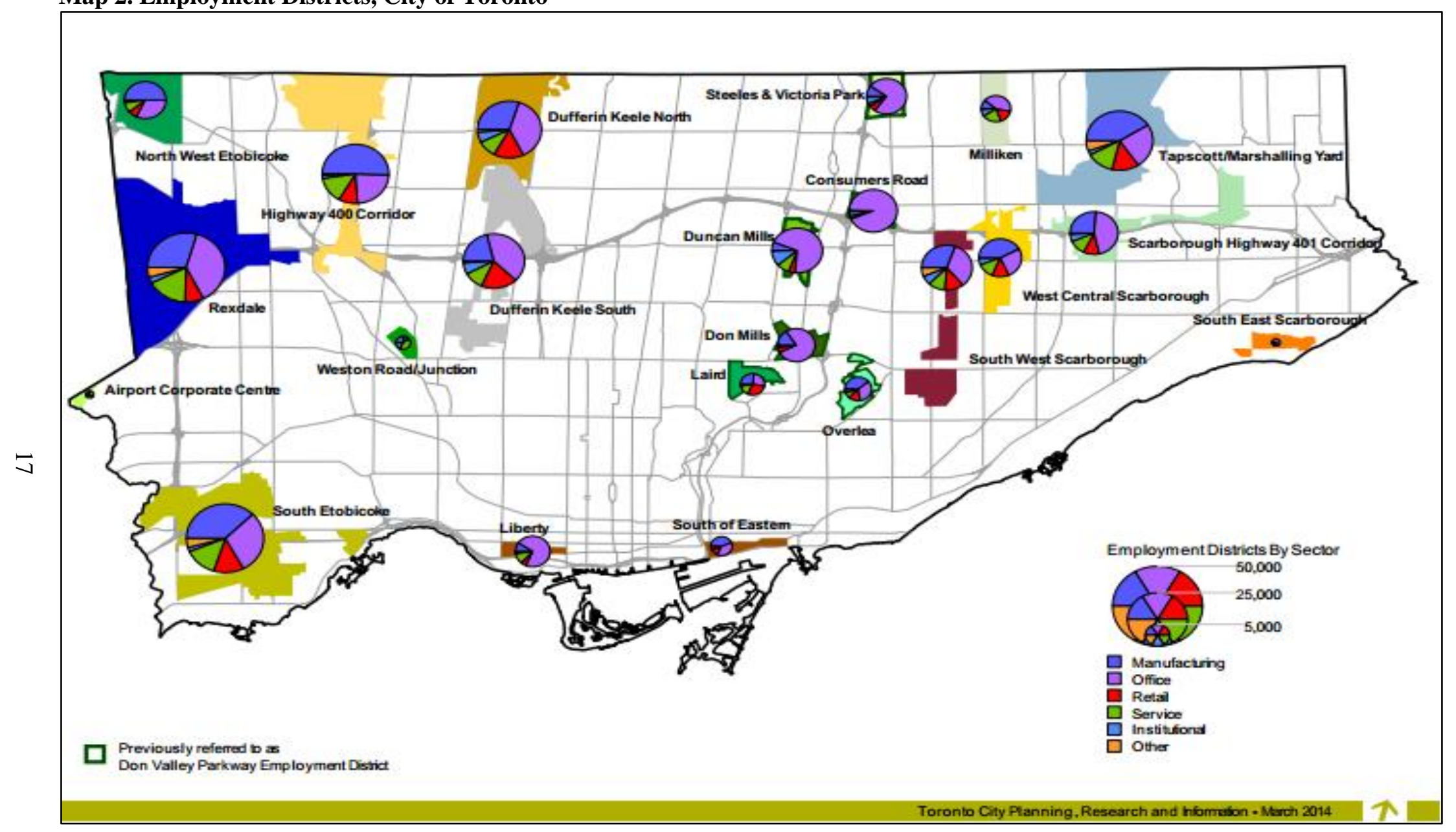

Source: Toronto Employment Survey, 2013, City of Toronto (2014: 15) 


\subsection{Immigrant-specific needs}

In Canada's settlement and integration framework, immigrants are typically categorized as homogenous service users, rather than a heterogeneous group with multiple intersecting identities, who requires a needs-based model of service delivery throughout the settlement trajectory (George, 2002). This has created a number of structural and social barriers in settlement and employment service provision which prevent newcomers from accessing and utilizing information, resources and tools needed to integrate in the Canada's labour market.

In an applied psychology study on immigrant job seeking behaviors in the Canadian workforce, Guerrero and Rothstein (2012:326) highlight an unfolding job search model for skilled immigrants (see Figure 3). The model discusses how three immigrant-specific factors shape the nature of job search, job search behaviours and job search outcomes.

Figure 3. Job search model for skilled immigrants

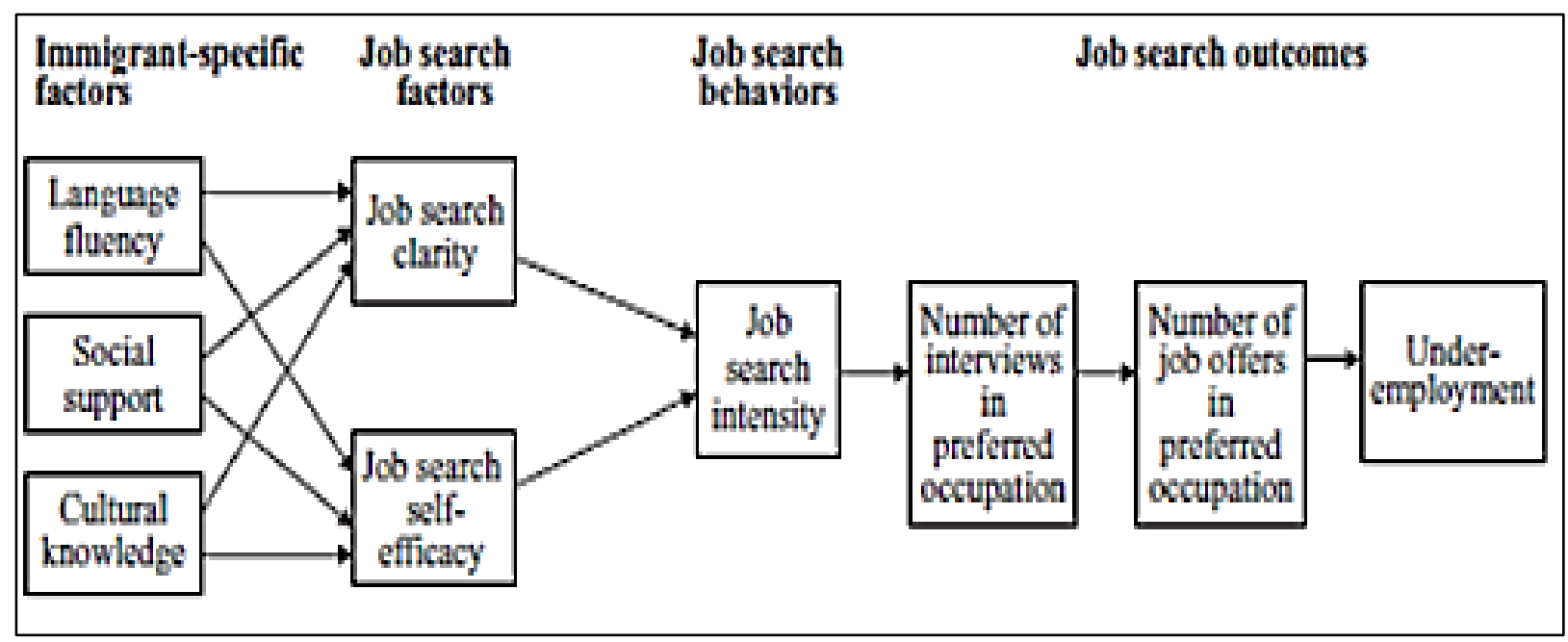

Source: Guerrero and Rothstein (2012: 326) 
Based on survey responses from skilled immigrants utilizing a Canadian non-profit job matching database, Guerrero and Rothstein (2012) uncovered that job search intensity acts as a strong mediator between job search factors and the number of job interviews for the preferred occupation. While the overall findings on immigrant job seeking behaviors are crucial to labour market success, Guerrero and Rothstein (2012) do not fully account for institutional barriers or direct experience with discrimination in the recruitment and selection process (Teelucksingh and Galabuzi, 2007) which can shape immigrant job search behaviors overtime. For example, the lack of foreign credential accreditation or Canadian experience is noted for shaping the types of low wage service sector work immigrants initially obtain and remain over represented in even after 10 years in the Canadian labour market (Block and Galabuzi, 2011; Galabuzi, 2006; Teelucksingh and Galabuzi, 2007). Aside from these limitations, the immigrant specific factors discussed by Guerrero and Rothstein (2012) shed insight on the unique and intersecting needs settlement and employment service provision should contain to ensure newcomers can fully access and utilize formal LMI resources and tools to find and retain work in the Canadian labour market.

i. Language fluency is characterized as the degree to which an individual is able to communicate verbally or in writing in the language of the receiving country (ibid). Fluency varies based on different intersecting needs and depends on different cultures of communicating (Essess and Medianu, 2012). According to Hall (2000), cultures can be situated in relation to one another through the styles in which they communicate. In North America, Scandinavian and German cultures communication occurs predominantly through explicit statements in text and speech, and they are thus categorized as 'LowContext' cultures (quoted in Essess and Medianu, 2012: 17). Whereas Japanese, Chinese, and the Filipino are characterized as 'high context' cultures who often draw on communicative cues such as body language, tone of voice, and gestures, and are also communicating through metaphors and subtle cues (ibid). 
The cross-cultural communication differences are an important consideration in employment and settlement programming since Canada continues to receive immigrants from 'high context' cultures. The contemporary wave of immigrants has significantly increased Canada's linguistic diversity with $14.2 \%$ of the population speaking a language other than English or French at home (Statistics Canada, 2011a). Between 2006 and 2011, Tagalog, a Philippine-based language, has increased by $+64 \%$ along with seven other languages by greater than 30\%. These includes Mandarin (+51\%), Arabic (+47\%), Hindi (+44\%), Creoles (+42\%), Bengali (+40\%), Persian $(+33 \%)$ and Spanish $(+32 \%)$ (ibid). In fact, Toronto has the most linguistically diverse groups with more than one-third of the population able to speak one of five ‘foreign' languages: Cantonese (8.8\%), Punjabi (8.0\%), Chinese (7.0\%), Urdu (5.9\%) and Tamil (5.7\%) (ibid). According to Statistics Canada (2011b), South Asian immigrants have the second highest proportion of languages and dialectics spoken in Canada compared to immigrants coming before 2006. Specifically, those identifying as Indian, Pakistani, Bangladeshi and Sri Lankan have a larger variation in languages spoken (see Table 1). This includes Indo-Iranian languages, 17.3\% (Punjabi, Urdu, Persian, Gujarati, Hindi) and Dravidian languages, 2.6\% (Tamil, Malayalam, Telugu). These outnumber other large immigrant groups, like Asians, who also speak various languages, ie. Chinese, Tibeto-Burman, Korean, Japanese, Tai-Kadai or Austro-Asiatic; as well as, Eastern, Southern and Central European immigrants, which include those speaking Romance, Germanic, Slavic and Finno-Urgric languages. The increase of South Asian immigrants in Canada coupled with variation in languages reinforce need for labour market information and other settlement information to be remitted in a tone that reflects the oral and written communication of different languages and regional dialectics. 
Table 1. Population of immigrant mother tongue families, showing main languages comprising each family, Canada, 2011

\begin{tabular}{|c|c|c|c|}
\hline Language family & Main languages & Number & Percentage \\
\hline Niger-Congo languages & Akan, Swahili, Rundi & 81,135 & 1.2 \\
\hline Cushitic languages & Somali, Oromo & 45,880 & 0.7 \\
\hline Semitic languages & Arabic, Hebrew, Amharic & 449,580 & 6.6 \\
\hline Turkic languages & Turkish, Azerbaijani & 36,750 & 0.5 \\
\hline Armenian & Armenian & 31,680 & 0.5 \\
\hline Indo-Iranian languages & Punjabi, Urdu, Persian, Gujarati, Hindi & $1,179,990$ & 17.3 \\
\hline Dravidian languages & Tamil, Malayalam, Telugu & 175,280 & 2.6 \\
\hline Chinese languages & Chinese $(n, 0, s, 2)$, Cantonese, Mandarin & $1,112,610$ & 16.3 \\
\hline Tibeto-Burman languages & Tibetan, Burmese & 8,210 & 0.1 \\
\hline Korean & Korean & 142,880 & 2.1 \\
\hline Japanese & Japanese & 43,040 & 0.6 \\
\hline Malayo-Polynesian languages & Tagalog, Ilocano, Malay & 443,750 & 6.5 \\
\hline Tai-Kadai languages & Lao, Thai & 22,615 & 0.3 \\
\hline Austro-Asiatic languages & Vietnamese, Khmer & 174,455 & 2.6 \\
\hline Romance languages & Spanish, Italian, Portuguese & $1,196,390$ & 17.5 \\
\hline Germanic languages & German, Dutch, Yiddish & 611,165 & 8.9 \\
\hline Slavic languages & Polish, Russian, Ukrainian & 721,605 & 10.6 \\
\hline Baltic languages & Lithuanian, Latvian & 14,055 & 0.2 \\
\hline Finno-Ugric languages & Hungarian, Finnish, Estonian & 96,200 & 1.4 \\
\hline Celtic languages & Welsh & 3,885 & 0.1 \\
\hline Greek & Greek & 117,890 & 1.7 \\
\hline Albanian & Albanian & 25,010 & 0.4 \\
\hline Creole languages & Haitian Creole & 75,255 & 1.1 \\
\hline Other languages & Kabyle, Georgian, Mongol & 29,410 & 0.4 \\
\hline \multicolumn{2}{|l|}{ All immigrant languages } & $6,838,705$ & 100 \\
\hline \multicolumn{4}{|c|}{$\begin{array}{l}\text { Notes: } \\
\text { 1. Language families are listed according to major region of origin: African and Middle Eastern languages are shown first, followed by Asian languages } \\
\text { (Indian subcontinent, East Asia and Southeast Asia), European languages and, finally, Creole languages, which come mainly from the Americas but are } \\
\text { also found in other regions such as the Indian Ocean. } \\
\text { 2. N.o.s. means 'not otherwise specified.' } \\
\text { Source: Statistics Canada, Census of Population, } 2011 \text {. }\end{array}$} \\
\hline
\end{tabular}

Source: Statistics Canada (2011b), Immigrant Languages in Canada

ii. Social support can include both professional and emotional support with job seeking from family, friends and any other personal network. Studies on the outcomes of leveraging social capital in newcomer communities' finds strength of social support can vary among newcomer communities (Xue, 2008; Ooka and Wellman, 2003). In job hunting, it has only reproduced existing racial/ethnic segregation pre- 
conditioned by Canada's immigration selection policies (Ooka and Wellman, 2003). Studies on the socioeconomic integration of immigrants attribute outcomes to different types of class based resources, ethnospecific resources, and employment/business strategies undertaken by immigrant communities (Qadeer 1999; Akter, Ropkara-Sarsu, Dyson, 2013). However, emerging informational perspectives suggest information relayed through ICTs and ethnic media play a pivotal role shaping the integration process and maintaining transnational ties between home and host country, especially among Asian diaspora (Aizlewood \& Doody, 2002 quoted in Caidi, Allard and Quirke, 2010; Kelly, 2003). Online engagement using ICTs, eg., chat rooms, listservs, newsgroups and audio/video conferences are utilized the most by immigrants (Caidi, Allard and Quirke, 2010). In her unpublished MA work, Chien (2005) examines these patterns on Settlement.Org, a Toronto based website produced by the Ontario Council of Agencies Serving Immigrants (OCASI) that provides settlement information to newcomers (quoted in Caidi, Allard and Quirke, 2010: 511-512). Her observations report that in conjunction with providing settlement information, the interactive wiki format of this website also allows immigrants to connect with both immigrants and Canadian-born. Through contributing content, sharing opinions and stories, and giving advice to others, recent immigrants are expanding and building strength of social support beyond similar co-ethnic ties (ibid).

iii. Cultural knowledge provides information about the cultural processes and behaviors newcomers need to adjust. Research by Thomas et.al (2008) indicates individuals with higher levels of cultural knowledge are likely to have a better understanding of their own behavior and others, more comfortable engaging in social interactions, and demonstrating effective cross-cultural behavior (Quoted in Caidi, Allard and Quirke, 2010: 82). Cultural knowledge on the Canadian workplace could improve recent immigrants' outcomes in various tests and interviews during the recruitment and selection process. Shields, Kelly, Murnaghan, Park, Lemoine (2011) note recent immigrants undergo similar employer screening in the recruitment process, with $70 \%$ going through personal interviews. Despite their job 
seeking in the short-term and long term, immigrants still earn less and remain largely over-represented in entry level service work compared to Canadian born (Block and Galabuzi, 2011). While other institutional barriers within the recruitment and selection process can prevent recent immigrants gaining access and mobility in the Canadian labour market, information on culture may improve their interpersonal capacities during interviews.

\subsection{Immigrant Labour market outcomes}

There is limited evidence to confirm labour market information is utilized and impacts the labour market decisions and outcomes for Canadian workers and employers (Murray, 2010). Even less know on the factors influencing information access and use by newcomers and the impact on their labour market outcomes (Caidi, Allard, Quirke, 2010; Esses and Medianu, 2012). However, labour market research continually demonstrates differential labour market outcomes for immigrants on the basis of race, class, gender and immigration status (Galabuzi, 2006; Teelucksingh and Galabuzi, 2007; Rietz 2007). These findings suggest labour market information, tools, and supports currently available have not been effective in alleviating the multiple barriers facing recent immigrants in Canadian labour market.

Quantitative analysis undertaken by The Toronto Immigrant Employment Data Initiative (TIEDI, 2012a) uncovered that even after four years in Canada recent immigrants have significantly higher unemployment rates and lower earnings compared to Canadian born and immigrants (Shields, Lo, Zikic and Atlin 2011:3). Figures 4, 5 and 6 adapted from TIEDI Analytical Report 2 highlight the overall differences in labour market outcomes by immigration class and gender (ibid). Principal applicants in the skilled worker classes had better labour market outcomes with lower unemployment, fewer jobless spells, higher earning and less time to acquire first jobs than other immigrant classes. Refugees experienced the greatest difficulties in the labour market among all recent immigrants. Gender disadvantages impact immigrant women of colour the most, producing higher unemployment rates, lower 
earnings, and access to education and training opportunities among all labour market participants (ibid).

Higher education typically translates to higher annual earnings (Preston, Damsbaek, Kelly, Lemoine, Lo, Shields and Tufts, 2010: 9). However, immigrants' annual earnings vary according to their country of origin (ibid). Among the 10 countries of birth examined (see Table 2), immigrants from Jamaica and Guyana are often the highest earners, while immigrants from China, Pakistan and Iran often have the lowest earnings (ibid). Differences in earnings between these groups can be largely tied to language fluency.

Figure 4. Unemployment rate by Immigration Class, 6 months, 2 years and 4 years after landing in Canada

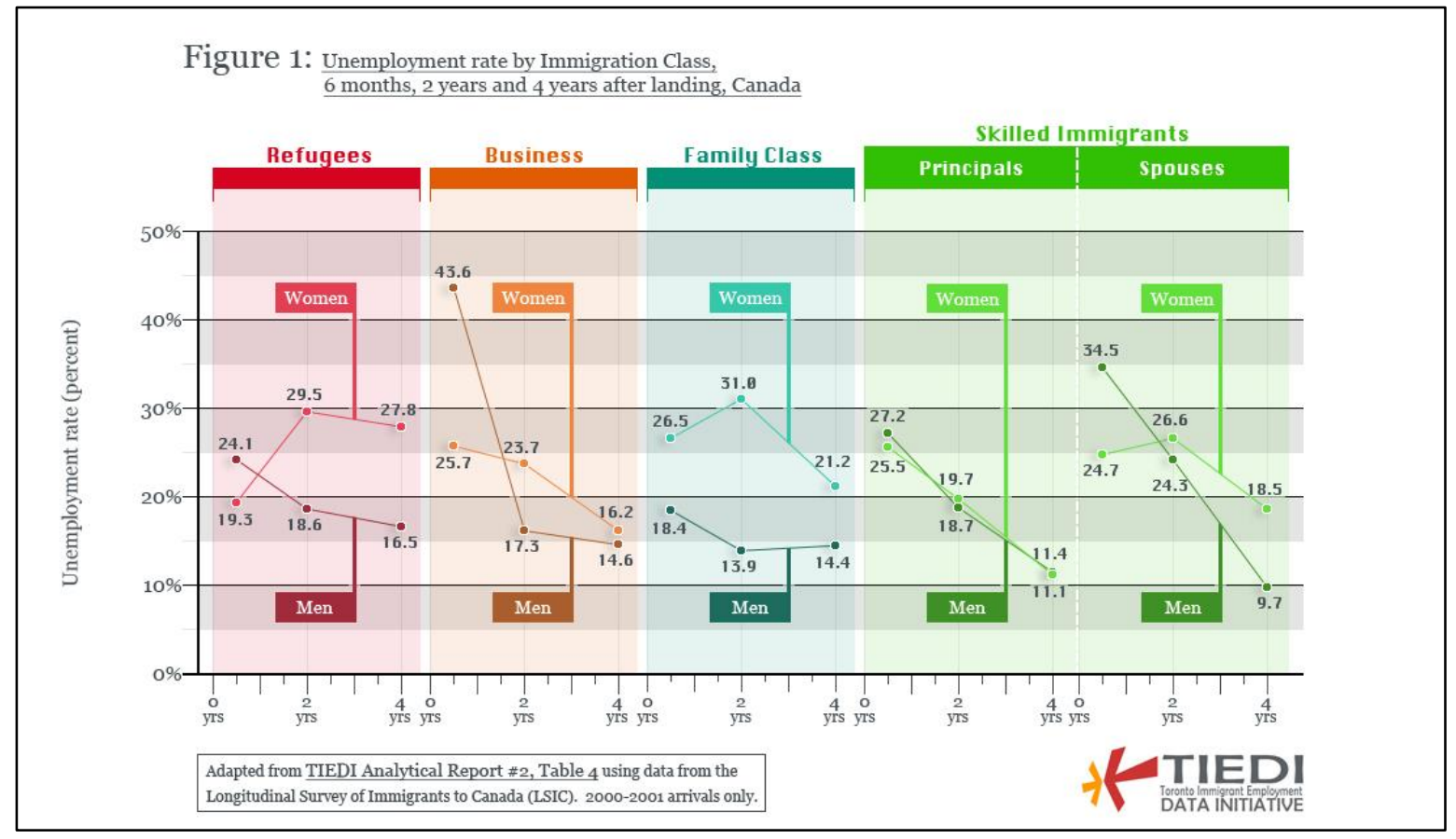

Source: Shields, Lo, Zikic and Atlin (2011: 3) 


\section{Figure 5. Full-time Employment by Immigration Class, 4 years after landing, Canada}

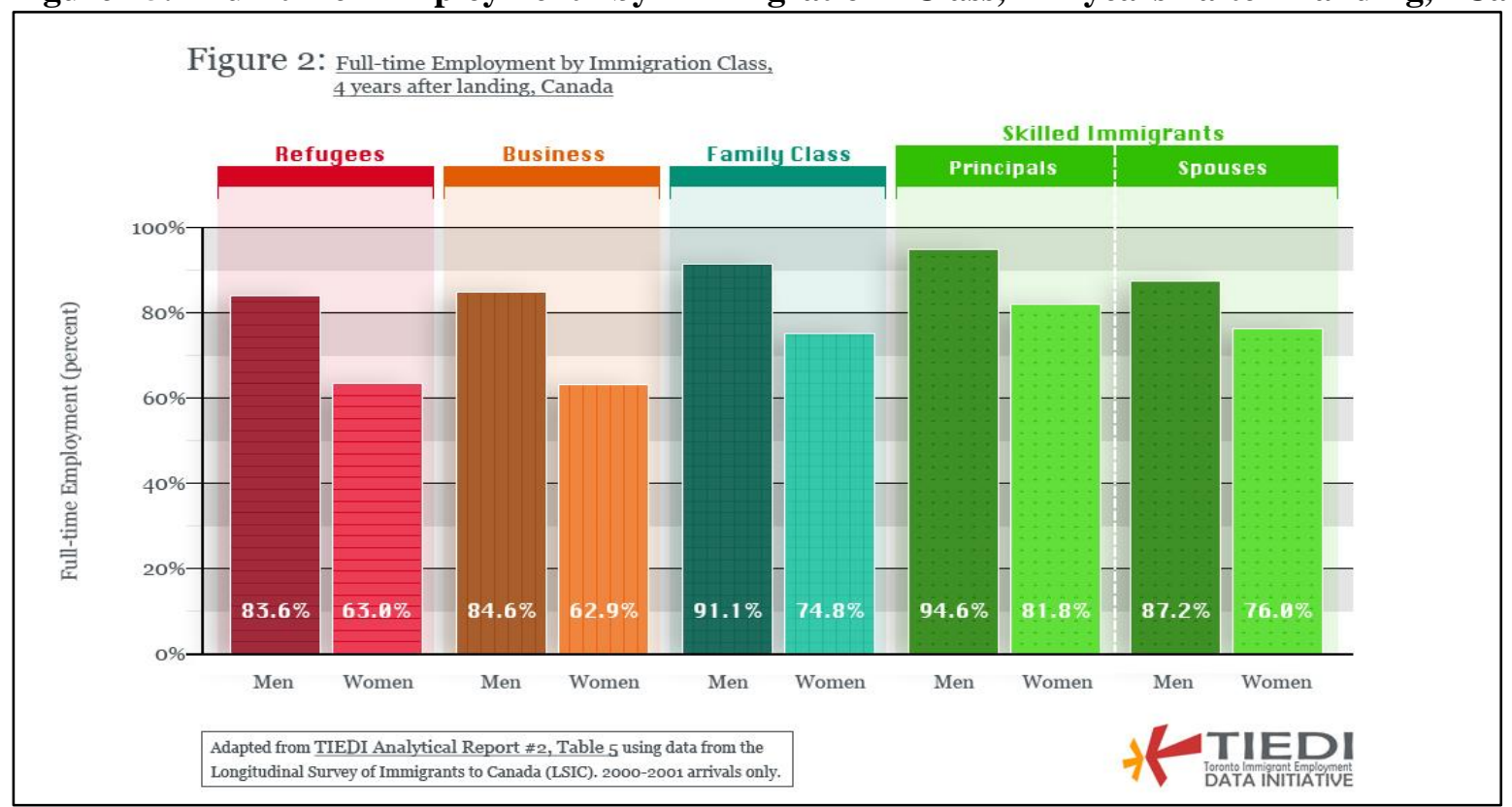

Source: Shields, Lo, Zikic and Atlin (2011:3)

Figure 6. Average Hourly Wage (2005 dollars) by Immigration Class, 2 years and 4 years after landing in Canada

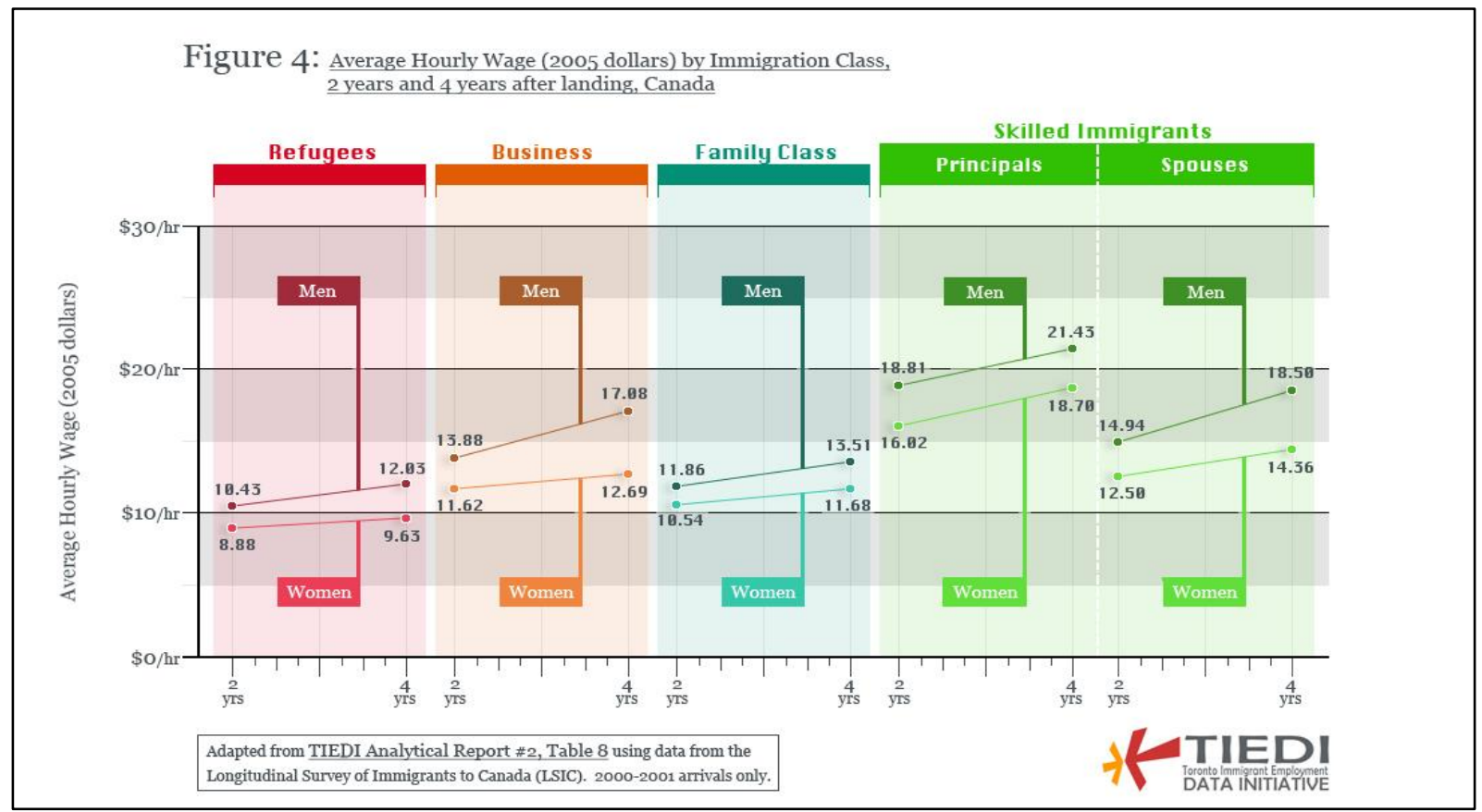

Source: Shields, Lo, Zikic and Atlin (2011:3) 
Table 2. Unemployment and Participation Rate for Immigrants by Educational Attainment and 10 Selected Countries of Birth, Toronto CMA

\begin{tabular}{|l|r|r|r|r|r|r|r|r|c|c|}
\hline \multirow{2}{*}{} & \multicolumn{9}{|c|}{ UNEMPLOYMENT RATE } & \multicolumn{4}{c|}{ PARTICIPATION RATE } \\
\cline { 2 - 11 } & $\begin{array}{c}\text { Less than } \\
\text { high school }\end{array}$ & $\begin{array}{c}\text { High } \\
\text { school }\end{array}$ & Trades & College & Univ. & $\begin{array}{c}\text { Less than } \\
\text { high school }\end{array}$ & $\begin{array}{c}\text { High } \\
\text { school }\end{array}$ & Trades & College & Univ. \\
\hline 1. PR China & $10.8 \%$ & $11.1 \%$ & $5.4 \%$ & $9.6 \%$ & $8.2 \%$ & $31.6 \%$ & $52.6 \%$ & $67.8 \%$ & $66.0 \%$ & $76.8 \%$ \\
\hline 2. India & $9.8 \%$ & $9.4 \%$ & $7.0 \%$ & $7.1 \%$ & $7.9 \%$ & $38.5 \%$ & $68.5 \%$ & $74.7 \%$ & $78.1 \%$ & $82.7 \%$ \\
\hline 3. Philippines & $12.8 \%$ & $6.4 \%$ & $6.0 \%$ & $4.4 \%$ & $4.8 \%$ & $35.7 \%$ & $72.5 \%$ & $78.2 \%$ & $82.0 \%$ & $82.6 \%$ \\
\hline 4. Hong Kong & $7.3 \%$ & $8.7 \%$ & $4.9 \%$ & $5.9 \%$ & $4.8 \%$ & $40.0 \%$ & $58.0 \%$ & $76.0 \%$ & $75.5 \%$ & $83.5 \%$ \\
\hline 5. Sri Lanka & $10.4 \%$ & $10.1 \%$ & $8.3 \%$ & $7.9 \%$ & $8.6 \%$ & $48.5 \%$ & $65.3 \%$ & $78.8 \%$ & $79.2 \%$ & $80.3 \%$ \\
\hline 6. Pakistan & $16.6 \%$ & $15.9 \%$ & $6.3 \%$ & $10.2 \%$ & $9.0 \%$ & $30.6 \%$ & $55.6 \%$ & $74.5 \%$ & $70.1 \%$ & $74.8 \%$ \\
\hline 7. Jamaica & $11.6 \%$ & $8.1 \%$ & $8.1 \%$ & $5.4 \%$ & $4.6 \%$ & $48.1 \%$ & $72.6 \%$ & $76.1 \%$ & $81.3 \%$ & $85.1 \%$ \\
\hline 8. Iran & $15.8 \%$ & $12.7 \%$ & $12.7 \%$ & $8.9 \%$ & $9.3 \%$ & $32.1 \%$ & $60.6 \%$ & $76.3 \%$ & $77.4 \%$ & $76.3 \%$ \\
\hline 9. Poland & $5.9 \%$ & $7.0 \%$ & $7.0 \%$ & $4.6 \%$ & $4.3 \%$ & $31.0 \%$ & $66.2 \%$ & $71.3 \%$ & $79.1 \%$ & $81.8 \%$ \\
\hline 10. Guyana & $8.4 \%$ & $8.6 \%$ & $8.6 \%$ & $5.3 \%$ & $5.3 \%$ & $47.1 \%$ & $72.4 \%$ & $81.1 \%$ & $82.5 \%$ & $85.8 \%$ \\
\hline
\end{tabular}

Source: Preston, Damsbaek, Kelly, Lemoine, Lo, Shields and Tufts (2010: 9)

Overtime, initial labour market outcomes remain relatively the same even after 10 years in Canada (Block and Galabuzi. 2011; Galabuzi, 2006; Teelucksingh and Galabuzi, 2007). However, country of birth and gender has become leading factors shaping the colour coded nature of the Canadian labour market (see Block and Galabuzi, 2011). This is specifically observed when examining the participation, unemployment and types of jobs undertaken racialized minorities, which largely includes West Asian/Arab, Black and South Asian groups in the Canadian labour market compared to Canadian born (Block and Galabuzi, 2011: 8, Table 2). There is generally an over-representation of racialized minorities in entry-level work in key industries and an under-representation in managerial positions (Block and Galabuzi, 2011). In particular, racialized minority men are overrepresented in Manufacturing (12.2\%), Transportation and Warehousing (11.9\%), Accommodation and Food Services (10.2\%) and under-represented in skilled trades' related occupations in Construction (6.2\%) (Block and Galabuzi, 2011:10). While racialized minority women are over-represented in Financial and Insurance (12.2\%), 
Health Care and Social assistance (11.3\%), Accommodation and food services (10.5\%); and underrepresented on the basis of gender in skilled trades related occupations in Construction (0.9\%) (ibid). In global cities, like Toronto, [the colour-coded] segmentation of immigrants in entry level servicebased work in the labour market has intensified over the last 20 years (TWIG 2011). A changing structure and nature of work continues to shrink middle class job opportunities and significantly expand more [non-standard employment work] in high end knowledge work and entry- level jobs in Toronto's downtown core (Ibid). In her global city thesis, Sassen (2001) explains this new hierarchy of services produces a "high-income gentrification" which intensifies competition in the labour market among all jobseeker. By nature of their recent entry in the market place "third world immigrants" have been forced to obtain low wage service work, while native-born workers are both represented and benefiting from in higher wage work (Ibid). In Toronto, this has become more pronounced under unfavorable market conditions coupled with young professionals, immigrants ( 5 years or more in Canada) and the Canadian born competing with newcomers for available opportunities at an entry level (Tal and Enenajor, 2013). The Chart 1, below represents the level of competition among all labour market participants for available employment opportunities in 2006. Although more recent tabulation has not been done using National Household Survey 2011, a similar pattern of immigrant and newcomer segmentation in entry level work exists, and if anything has expanded into the proportion of youth, sales or server jobs. 


\section{Chart 1. Proportion of individuals by immigrant status employed in Entry-level job categories}

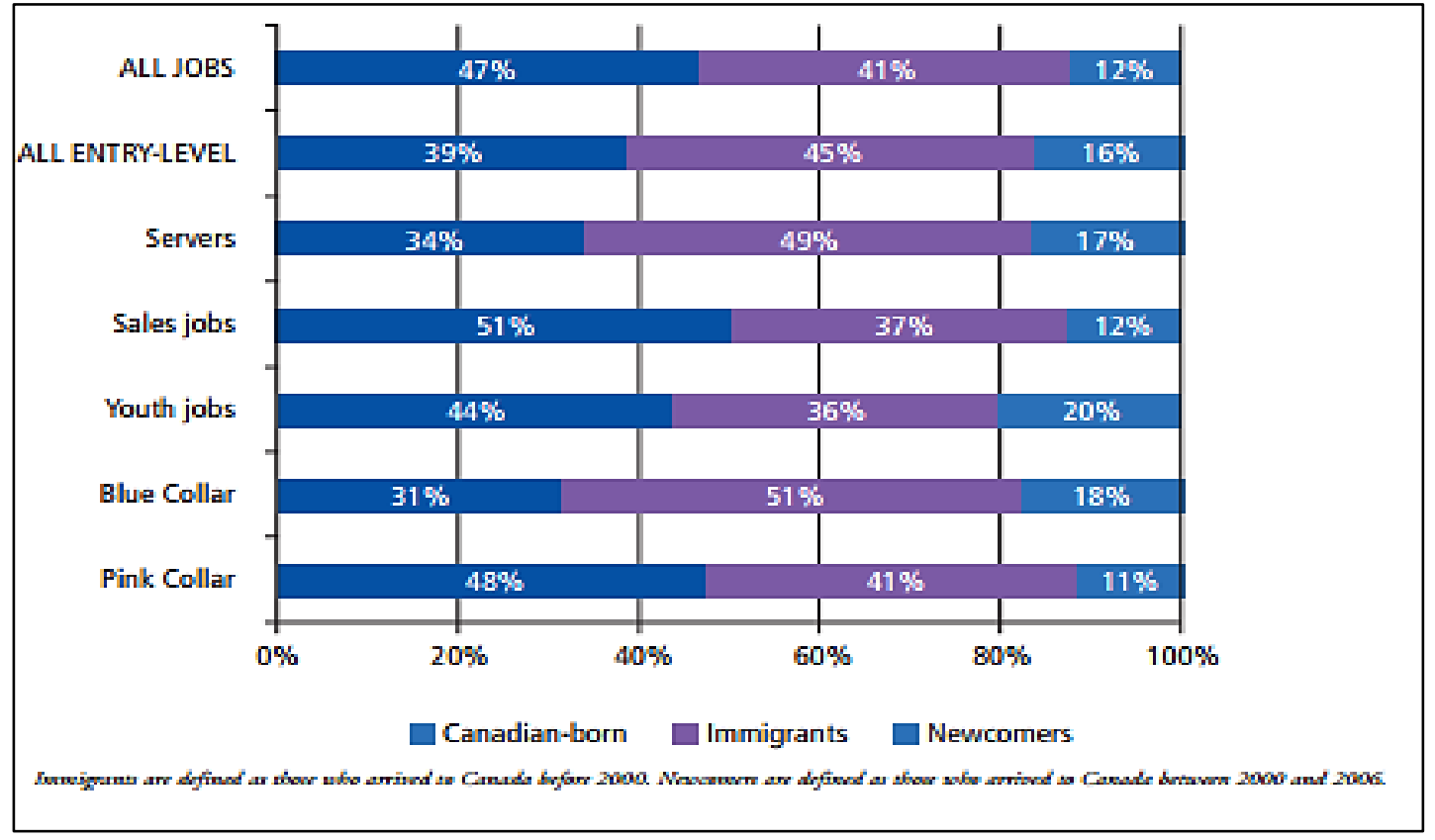

Source: TWIG (2011:28), Sifting Through the Sands: Unpacking the Hourglass

To further explore antecedents of immigrant labour market integration issues in Toronto, the TIEDI project also assessed a number of variables collected by official datasets, including Longitudinal Survey of Immigrant to Canada (LSIC) and Workplace Employee Survey (WES). The finding reveals recent immigrants face multiple labour market integration barriers. Most are linked to issues with foreign credential accreditation process and the lack of Canadian work experience, which could be alleviated with better pre-arrival preparation. When examining immigrant experiences of accreditation processes in different occupations, immigrants planning to work in unregulated occupations fared only slightly better than those planning to work in regulated occupations (Tufts, Lemoine, Phan, Kelly, Lo, Preston, Shields, 2010). Credential recognition difficulties were most experienced by immigrants planning to work in the health care sector (27.1\%), compared to natural science, engineering, and architecture (72.9\%) (ibid). The pronounced difficulties with integrating into healthcare occupations certainly reflect the poor labour market supply and demand outlook for International Medical graduates (IMG) whose foreign credentials 
are not accepted and/or transferable to Ontario's emerging e-health care systems (Routestoemployment.ca). But these labour market outcomes of international medical graduates and other occupations can also be attributed to the types of pre and post arrival LMI recent immigrants are found to use or not use. Before arriving many recent immigrants did check whether credentials were recognized, but for the minority who did not, reasons for not doing so included: credentials are good and were not looking for work; a lack of time; not necessary because they knew their credentials would be accepted via word of mouth; and don't know how (see, Figure 7 adapted from TIEDI Analytical report \#15). Upon arrival, only a small number of immigrants used job search information obtained from news stories (2.9\%), union postings (less than $1 \%$ ), and recruitment agencies or headhunters (4.5\%). Evidently, this proved to create higher hourly wages than commonly used sources of information, family and friends (42.1\%) and personal initiative (22.2\%) (Fang, Damsbaek, Kelly, Lemoine, Lo, Preston, Shields, Tufts, 2010). See below TIEDI's comparative breakdown on average hourly wage (2005 dollars) for Canadianborn and immigrants by period of immigration and source of information for finding their current job in Canada (ibid, Table 3).

These observations indicate a disjuncture exists between recent immigrants and the formal and informal LMI intermediaries about the realities of what LMI is needed or should be utilized versus what is provided. Without full consideration or access to pre-arrival LMI on credentials assessment as well as reliable LMI post arrival support, recent immigrants are more likely become confused, unaware of realities of current labour market demands and ineffectively attempt to undertake job matching that does not make use of their foreign skills. This largely echoes concerns about highly fragmented and uncoordinated LMI provision in Canada's labour force development system raised by Advisory Panel on Labour Market Information (2009) and Drummond (2014). 
Figure 7. Reason for not checking credentials **by regulated occupation and gender, Canada

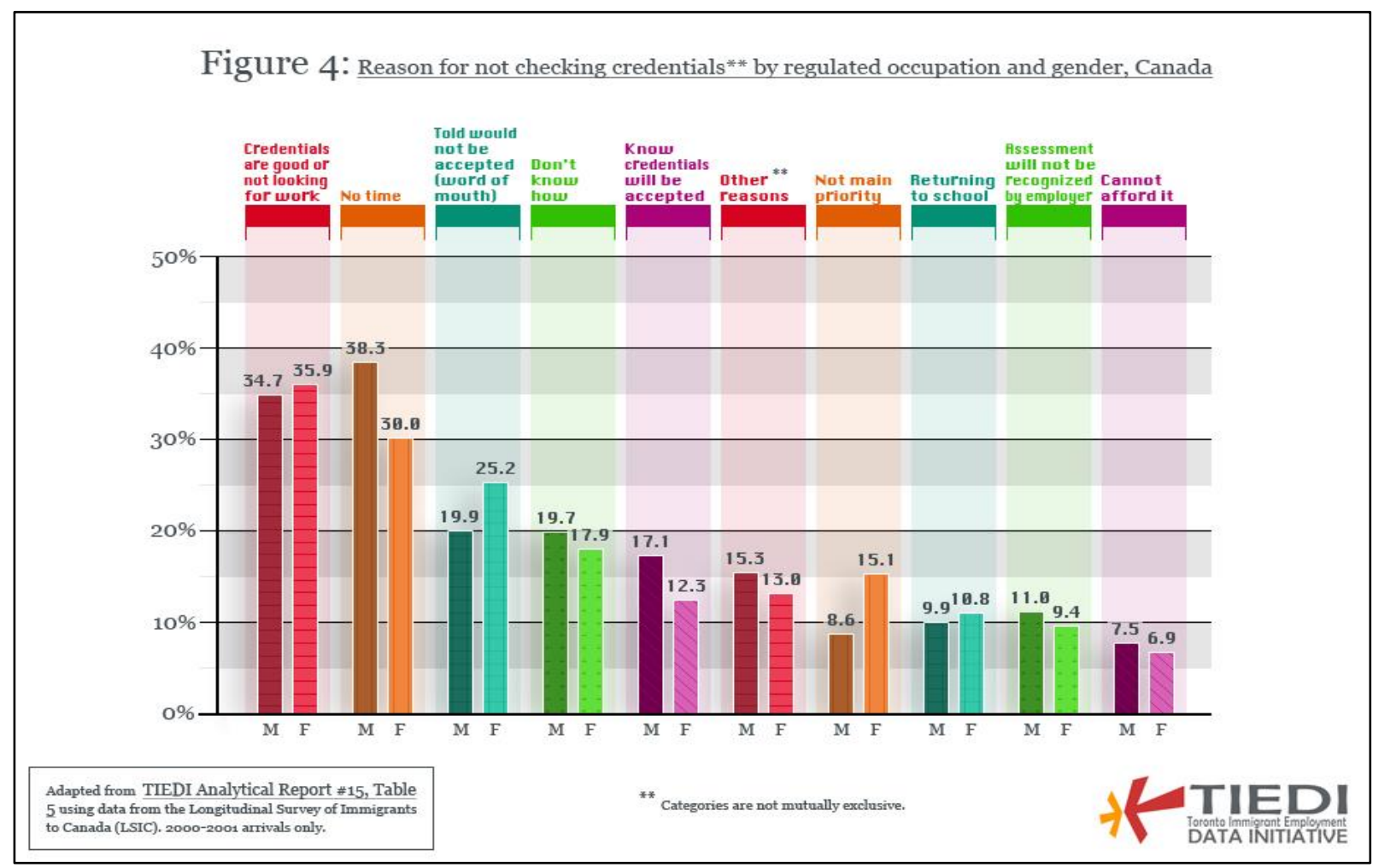

Source: Zikic, Lemoine, Phan, Kelly, Fang, Preston and Tufts (2011)

Table 3. Average hourly wage (2005 dollars) for Canadian-born and immigrants by period of immigration and source of information for finding current job, Canada

\begin{tabular}{|c|c|c|c|c|c|c|}
\hline & \multirow[t]{2}{*}{ CANADIAN-BORN } & \multicolumn{5}{|c|}{ IMMIGRNNT } \\
\hline & & ALI IMMIGRANTS & BEFORE 1980 & $1981-1990$ & $1991-2000$ & $2001-2003$ \\
\hline Family or friend & $\$ 20.60$ & $\$ 20.10$ & S 23.30 & $\$ 24.20$ & $\$ 16.30$ & $\$ 14.80$ \\
\hline Personal initiative & \$ 20.80 & $\$ 20.00$ & $\$ 22.90$ & $\$ 19.20$ & $\$ 16.70$ & $\$ 19.40$ \\
\hline Help wanted ad & \$ 21.00 & $\$ 22.00$ & $\$ 24.50$ & $\$ 21.10$ & $\$ 19.40$ & $\$ 14.80$ \\
\hline Directly recruited by employer & $\$ 24.10$ & $\$ 22.20$ & $\$ 24.00$ & $\$ 20.40$ & $\$ 20.80$ & $\$ 18.30$ \\
\hline Internet & $\$ 22.90$ & $\$ 24.90$ & $\$ 26.60$ & $\$ 22.50$ & $\$ 25.10$ & $\$ 23.80$ \\
\hline Recruitment agency (headhunter) & \$ 30.40 & S 27.30 & $\$ 31.00$ & $\$ 28.30$ & $\$ 23.30$ & $\mathrm{n} / \mathrm{a}$ \\
\hline $\begin{array}{l}\text { Canada Employment Centre } \\
\text { (or government agency) }\end{array}$ & S 18.20 & \$ 20.10 & \$ 22.30 & $\$ 22.70$ & $\$ 17.80$ & $\$ 14.30$ \\
\hline News story & $\$ 20.60$ & $\$ 29.40$ & \$ 31.70 & $\mathrm{n} / \mathbf{a}$ & n/a & $\mathbf{n} / \mathbf{a}$ \\
\hline On-campus recruitment & \$ 30.70 & S 26.80 & \$ 29.90 & $\$ 28.50^{* *}$ & $\$ 17.00$ & $\mathbf{n} / \mathbf{a}$ \\
\hline Union posting & S 28.60 & S 28.10 & \$ 32.20 & $\mathrm{n} / \mathrm{a}$ & $\mathrm{n} / \mathrm{a}$ & $\mathbf{n} / \mathbf{a}$ \\
\hline Job fair & $\$ 19.60$ & $\$ 23.00$ & $\$ 21.80$ & $\mathrm{n} / \mathbf{a}$ & $\mathrm{n} / \mathrm{a}$ & $\mathrm{n} / \mathrm{a}$ \\
\hline Other & $\$ 25.20$ & S 28.10 & S 33.40 & $\$ 25.10$ & $\$ 21.10$ & $528.20^{=4}$ \\
\hline
\end{tabular}

n/a: Data suppressed due to reliability and/or confidentiality issues **: Potential reliability issues. Use with caution.

Source: Fang, Damsbaek, Kelly, Lemoine, Lo, Preston, Shields and Tufts (2010: 6) 
The literature confirms Caidi, Allard and Quirke's findings (2005:520) that "One of the most significant information needs a newcomer faces has to do with finding employment (George et al., 2004). However, no studies within the information literature specifically address how immigrants find employment or make use of employment information to secure work [in Canada]". The statistical portrait of labour market outcomes among recent immigrants suggests there are different structural and social barriers in seeking employment in the Canadian labour market. Despite the large number of employment information, services and supports available it may not be conducive, accessible, or tailored to meet the specific/intersecting needs of newcomers. Current labour force development discussions only capture general issues with LMI collection, interpretation and dissemination and the impact it has on how labour market participants can obtain and utilize for making labour market decisions. There is still much to learn on about the impact of LMI provision on particular job seeking groups, especially recent immigrants whose labour market integration can be better support at an early stage with relevant information, tips and tools. To gain further insight about factors influencing how recent immigrants obtain or make use of employment information to secure work first requires re-examination on the nature of LMI provision in Canada's labour force development system. To first uncover what and how labour market information is provided to recent immigrants, pre and post arrival? Followed by an assessment on how the labour market information provided in pre and post arrival stages can support/advance labour market integration of recent immigrants?

\section{METHODOLOGY}

To further explore informational factors influencing how recent immigrants obtain and utilize LMI to inform and support labour market decisions when seeking employment in Canada's labour market, a qualitative content analysis is the most appropriate research method. A content analysis is a widely used method of document analysis firmly established in communication, social science, 
psychology and business studies (Elo and Kyngäs, 2008). This technique objectively and systemically identifies specified characteristics of messages and makes inferences about the information conveyed in document(s) using deductive and/or inductive analyses (ibid). The outcomes are key concepts or categories identified and discussed to help explain a phenomenon (ibid).

\subsection{Data collection}

Due to a lack of time and resources available for this research study, the scope and size of labour market information collection sample had to be reduced to a small-scale qualitative content analysis. Types of LMI collected and assessed was limited to information, flyers, leaflets and pamphlets made publicly available online and in-person by key LMI providers. Additionally, the scope of data collection and analysis was geographically narrowed to Toronto in response to heightened challenges recent immigrants face with gaining access to any available employment opportunity increasingly centralized in Toronto's downtown core (Tal and Enenajor, 2013). To examine how LMI is provided in both pre and post arrival stages of the settlement trajectory, a mix method of sampling was deployed since both phases have samples which vary in size from small cases to large numbers (Teddlie and Yu, 2007).

For the pre-arrival stage, purposive sampling methods relied on literature review and my local workforce development experience at the Toronto Workforce Innovation Group to select eleven online sources, see Appendix 1. The selected sources are identified as key LMI players in Canada's labour force development system with particular initiatives and tools designed for early stages of settlement and labour market integration. The total sample of eleven (11) selected sources draw on the LMI provided by federal government $(n=2)$, a federal-provincial partnership initiative $(n=1)$, a provincial government initiative $(n=1)$, municipal government $(n=1)$, local workforce planning board $(n=2)$, education and training body $(n=2)$, and universal service provider $(n=2)$. Purposive sampling is acceptable given the small number of cases or units (Teddlie and Yu, 2007) of pre arrival LMI initiatives at a micro level in Toronto and on a macro level, in Ontario and across Canada. Reliance on my professional expertise as labour market 
researcher with the Toronto Workforce Innovation Group may inherently create selection bias. However, policy-based literature verifies these selections are leading LMI players in Canada's labour force development system (Advisory Panel on Labour Market Information, 2009; Criptoph 2003; Esses and Medianu, 2012; Sharpe and Qiao, 2006).

For the post arrival stage, stratified random sampling was necessary given large number of providers and locations where LMI can be obtained in person and online (Teddlie and Yu, 2007). For example, NGO providers in the Employment Ontario network alone included 50+ employment agencies with over 60 locations across Toronto. To ensure the LMI collected and assessed is representative of LMI provided by all key providers outlined in literature, seven main stratums were first identified. Next, using local service directories, Emplyomentontario.ca and 211Toronto.ca each organization was identified and grouped on a collectively exhaustive basis to ensure each provider was included in any relevant stratums. This was done especially for NGO providers who are noted to fall under one or more strata depending on their role and community mandate (Biles et al., 2011). After seven different strata samples were compiled, two simple random selections were generated from each set. The total post arrival sample has fourteen (14) selected sources which include: Municipal government providers $(n=11)$, Education and Training Institutions ( $n=45)$, Industry and Regulatory bodies $(n=40)$, Immigrant Serving Agencies $(n=77)$, Issued-based NGO $(n=116)$, Multicultural NGO $(n=114)$ and Universal Service Providers $(n=19)$. All fourteen selected sources of post-arrival LMI are listed in Appendix 2.

It is important to note the pre and post arrival samples created for this small scale qualitative content analysis may not reflect the total number of available LMI portals online and in-person from formal providers in Canada's labour force development system. This can be attributed to the types of sources cited through literature, informed by my professional labour market research experience, and other organizations not registered on service directories, ie. Employmentontario.ca, 211Toronto.ca. 


\subsection{Data analysis}

The literature review captures only general LMI provision issues in Canada's labour force development system (Advisory Panel on Labour Market Information, 2009) and settlement framework (Esses and Medianu, 2012). This limits our understanding on what may or may not influence how newcomers can obtain and utilize LMI to inform and support their job hunting process in Canada's labour market. Since this study aims to enlarge informational perspectives on immigrant labour market integration in Canada, a deductive approach in the content analysis can mobilize discussions from general to more specific categories (Burns and Grove 2005 quoted in Elo and Kyngäs, 2008: 109).

After reviewing informational issues in Canada's settlement framework, Esses and Medianu (2012:21-25) conclude with suggestions that new models of settlement information processing should consider the psychological model of persuasive communication, pioneered by Chaiken (1987) and Petty \& Cacioppo (1986). Three main factors can be examined to understand what influences newcomers access and use of information, see Figure 8. First, the source and context of information provision can influence newcomers' likelihood of utilizing information based on credibility, i.e. perceived expertise, trustworthiness, similarity to intended target audience, eg. testimonials from other immigrants (ibid). Second, the location and timing can shape the level of reach or spatial proximity. Third, the content, format and target of the message can influence how specific users with intersecting needs can access, understand, and utilize information provided.

Given the noticeable research gaps about informational issues associated with labour market integration of recent immigrants in Canada, Esses and Medianu suggestions are used as a starting point to explore in this study (2012: 21-25). Examining all three factors enabled different layers of analysis to build a relational qualitative content analysis, a process focused on examining the relationships between words or concepts, not just the word or the concept (Wilkinson and Birmingham, 2003: 78-79). A 
relational analysis commonly undertakes 'affect extraction' to provide an emotional assessment of themes and issues based on perceived similarities; proximity analysis to scan for the information which meets the needs to target; and cognitive mapping to gather an overall understanding based on text and graphics (ibid).

Figure 8. A Model of Factors that May Influence Information Access and Use by Newcomers

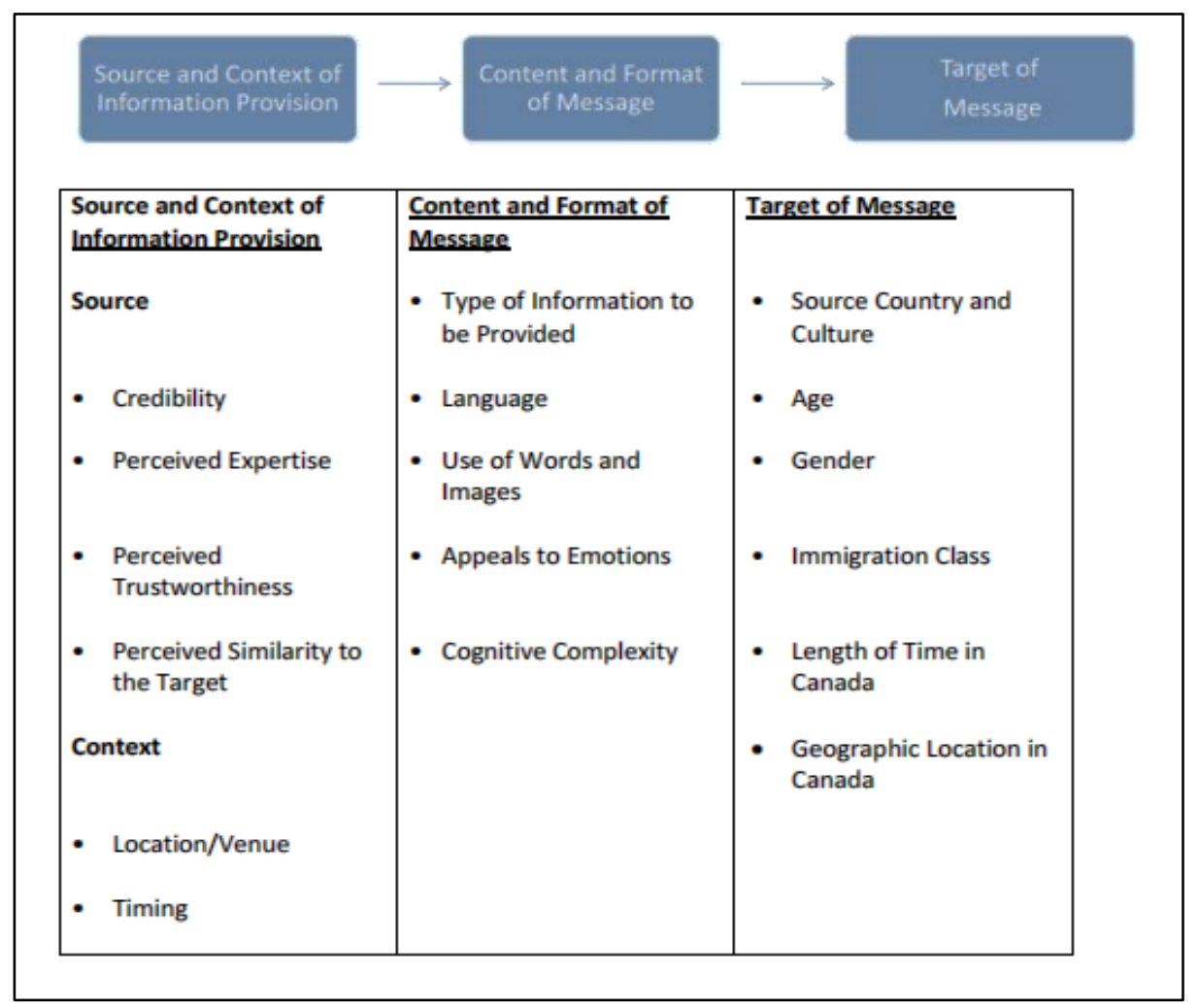

Source: Esses and Medianu (2012: 21)

However, only some elements of each were objective measures to assess within the parameters of this study. Several variables listed for examination under the source and context of provision and content and format of message are difficult to assess given that every job seeker has unique needs and purposes for utilizing LMI (Caidi, Allard, and Quirke, 2010). These included perceived expertise, perceived trustworthiness, perceived similarity to target, use of words and images, appeals to emotions and 
cognitive complexity. An accurate assessment would require other investigative techniques which directly engages and solicits the perspectives of prospective and recent immigrants seeking employment in Toronto or other regions about how to make sense of LMI available.

To ensure reliability and validity throughout this deductive approach, a structured analysis matric was developed and data contained in documents/resources were coded according to the categories. The structured analysis matric used for coding all variables is outlined in Appendix 3. The most detailed matric was developed to accurately identify and assess the types of LMI provided in the content on four basic employability dimensions. According to Canadian employment and settlement practitioners, there are four basic employability dimensions which each job seeker requires and should be assessed on a 'needs based model' to determine the type of assistance required (OCASI-LearnAtWork, 2014; Amundson, 2003; Redekopp, Hopkins and Hiebert, 2013; White Mountain Consulting, n.d). The framework for four basic employability dimensions was pioneered by Patsula (1992) based on different themes raised on understanding and working with various issues in employment counselling and since developed in employability framework for HRSDC and other labour force players (Amundson, 2003). The four basic employability dimensions are: 1) career decision making; 2) skills enhancement; 3) job search, and 4) employment maintenance (OCASI-LearnAtWork, 2014; Amundson, 2003; Redekopp, Hopkins and Hiebert, 2013; White Mountain Consulting, n.d). Career decision making refers to one's ability to determine what particular career field is related to their situation (White Mountain Consulting, n.d; Amundson, 2003). Skills enhancement refers to one's ability to develop generic skills, ie. literacy, numeracy, interpersonal, self-management and occupational/vocational skills associated with performing specific occupation(s) (ibid). Job search refers one's ability to conduct a job search independently using a variety of job search techniques (ibid). Employment Maintenance refers to one's ability to maintain stable employment, have control over it or personal stability during unemployment and job search (ibid). Each dimension has key elements which job seekers are looking for available supports to gain access and 
entry into the Canadian labour market. Throughout the deductive content analysis process, a good amount of time was spent sifting through LMI obtained to identify the quantity and quality of coverage on four basic employability dimensions.

\section{FINDINGS}

For prospective and recent immigrants seeking information to support or inform job hunting process in Toronto, there is an overwhelming quantity of information made available by formal providers. The nature of LMI provision for formal providers remains highly fragmented with varied coverage on basic employability dimensions, i.e. career decision making; skills enhancement; job search; and employment maintenance. These findings are consistent with issues identified in Canada's national labour force development discussions by Advisory Panel on Labour Market Information (2009) and Drummond (2014). As well as, issues continually raised by career/employment practitioners working in Toronto's Employment Ontario network; and national Canadian career development consultations recently undertaken in Alberta and Manitoba (Redekopp, Hopkins, Hiebert, 2013)

For a visual summary on the nature of LMI provision at pre and post arrival stages see, Tables 4 and 5. Table 4 captures general quantity of information available from eleven select sources to inform and support pre-arrival job hunting in Toronto. Table 5 captures the general quantity of information available from fourteen randomly selected sources, in-person and online. These include education and training bodies, government, industry and regulated bodies, and four NGO providers, ie. Immigrant serving agencies, issue-based and multicultural NGOs. The limited amount of time and resources to conduct this content analysis may not conclusively capture the full amount and quality of information publically available for prospective and recent immigrants to obtain online and in-person for both pre and initial post arrival stage. In sum, the findings provide general overview on some specific informational issues which 
can guide further research needed to contextualize the factors influencing how recent immigrants can obtain and make sense available LMI for job hunting in the Canadian labour market. 
Table 4. Pre-arrival LMI provision for newcomers from 11 selected online sources $^{2}$

\begin{tabular}{|c|c|c|c|c|c|c|c|c|}
\hline \multirow{2}{*}{$\begin{array}{l}\text { PRE-ARRIVAL } \\
\text { LMI SOURCES }\end{array}$} & \multirow{2}{*}{ TYPE OF PROVIDER } & \multicolumn{4}{|c|}{$\begin{array}{l}\text { LMI PROVISION ON BASIC EMPLOYABILITY } \\
\text { DIMENSIONS }\end{array}$} & \multicolumn{3}{|c|}{ LANGUAGE(S) } \\
\hline & & $\begin{array}{c}\text { Career } \\
\text { Decision } \\
\text { Making }\end{array}$ & $\begin{array}{c}\text { Skills } \\
\text { Enhancement }\end{array}$ & $\begin{array}{c}\text { Job } \\
\text { Search }\end{array}$ & $\begin{array}{l}\text { Employment } \\
\text { Maintenance }\end{array}$ & English & French & Other \\
\hline Work In Canada & Federal Government & $\bullet$ & $\bullet$ & $\Delta$ & & $\bullet$ & $\bullet$ & \\
\hline Job Bank & Federal Government & $\bullet$ & $\bullet$ & $\bullet$ & & $\bullet$ & $\bullet$ & \\
\hline $\begin{array}{l}\text { Canadian Immigrant } \\
\text { Integration Program }\end{array}$ & Federal-Provincial Partnership & $\bullet$ & $\bullet$ & $\Delta$ & & $\bullet$ & $\bullet$ & \\
\hline $\begin{array}{l}\text { Global Experience } \\
\text { Ontario }\end{array}$ & Provincial Government & $\bullet$ & $\bullet$ & $\Delta$ & & $\bullet$ & $\bullet$ & $\bullet$ \\
\hline $\begin{array}{l}\text { City of Toronto, } \\
\text { Immigration Portal }\end{array}$ & Municipal Government & $\bullet$ & $\bullet$ & $\bullet$ & $\bullet$ & $\bullet$ & & \\
\hline Routestoemployment.ca & Local workforce planning board & $\bullet$ & $\bullet$ & $\Delta$ & & $\bullet$ & $\bullet$ & \\
\hline Routestotrades.ca & Local workforce planning board & $\bullet$ & $\bullet$ & $\Delta$ & & $\bullet$ & & \\
\hline $\begin{array}{l}\text { World Education } \\
\text { Services }\end{array}$ & Education and Training body & $\bullet$ & $\bullet$ & $\Delta$ & & $\bullet$ & & \\
\hline $\begin{array}{l}\text { Canadian Information } \\
\text { Centre for International } \\
\text { Credentials }\end{array}$ & Education and Training body & $\bullet$ & $\bullet$ & $\Delta$ & & $\bullet$ & $\bullet$ & \\
\hline Settlement.org & Universal Service Provider & $\bullet$ & $\bullet$ & $\Delta$ & $\bullet$ & $\bullet$ & $\bullet$ & $\bullet$ \\
\hline Inmylanguage.org & Universal Service Provider & $\bullet$ & $\bullet$ & $\Delta$ & $\bullet$ & $\bullet$ & $\bullet$ & $\bullet$ \\
\hline
\end{tabular}

${ }^{2}$ - represents general coverage on some or all job seeking needs/activities for basic employability dimensions and other languages

$\Delta$ represents indirect access to job boards/posting on key sites which frequently include, Job Bank 
Table 5. Post-arrival LMI provision for newcomers from 14 selected sources $^{3}$

\begin{tabular}{|c|c|c|c|c|c|c|c|c|}
\hline \multirow[b]{2}{*}{$\begin{array}{l}\text { POST-ARRIVAL } \\
\text { LMI SOURCES }\end{array}$} & \multirow[b]{2}{*}{ TYPE OF PROVIDER } & \multicolumn{4}{|c|}{$\begin{array}{c}\text { LMI PROVISION ON BASIC EMPLOYABILITY } \\
\text { DIMENSIONS }\end{array}$} & \multicolumn{3}{|c|}{ LANGUAGE(S) } \\
\hline & & $\begin{array}{c}\text { Career } \\
\text { decision } \\
\text { making }\end{array}$ & $\begin{array}{c}\text { Skills } \\
\text { enhancement }\end{array}$ & $\begin{array}{c}\text { Job } \\
\text { search }\end{array}$ & $\begin{array}{l}\text { Employment } \\
\text { Maintenance }\end{array}$ & English & French & Other \\
\hline TDSB & Education and Training & $\bullet$ & $\bullet$ & $\Delta$ & $\bullet$ & - & & \\
\hline TCDSB & Education and Training & & $\bullet$ & & & $\bullet$ & & \\
\hline $\begin{array}{l}\text { College of Dental } \\
\text { Technologists of Ontario }\end{array}$ & Industry Regulatory Body & $\bullet$ & $\bullet$ & & $\bullet$ & $\bullet$ & & \\
\hline $\begin{array}{l}\text { College of Midwives of } \\
\text { Ontario }\end{array}$ & Industry Regulatory Body & $\bullet$ & $\bullet$ & & $\bullet$ & $\bullet$ & & \\
\hline TESS-Attwell & Municipal Government & $\bullet$ & $\bullet$ & $\bullet$ & $\bullet$ & $\bullet$ & & $\bullet$ \\
\hline TESS-Parkdale/High Park & Municipal Government & $\bullet$ & $\bullet$ & $\bullet$ & $\bullet$ & $\bullet$ & & $\bullet$ \\
\hline $\begin{array}{l}\text { Heritage Skills Development } \\
\text { Centre }\end{array}$ & $\begin{array}{l}\text { Immigrant Serving Agency } \\
\text { (ISA) NGO }\end{array}$ & $\bullet$ & $\bullet$ & & & $\bullet$ & & \\
\hline University Settlement & $\begin{array}{l}\text { Immigrant Serving Agency } \\
\text { (ISA) NGO }\end{array}$ & $\bullet$ & $\bullet$ & $\bullet$ & $\bullet$ & $\bullet$ & & $\bullet$ \\
\hline $\begin{array}{l}\text { KCWA Family and Social } \\
\text { Services }\end{array}$ & Issue-based NGO & $\bullet$ & $\bullet$ & $\Delta$ & & $\bullet$ & & $\bullet$ \\
\hline $\begin{array}{l}\text { ACCES Employment, } \\
\text { Scarborough }\end{array}$ & Issue-Based NGO & $\bullet$ & $\bullet$ & $\bullet$ & $\bullet$ & $\bullet$ & & $\bullet$ \\
\hline $\begin{array}{l}\text { Centre Francophone de } \\
\text { Toronto }\end{array}$ & Multicultural NGO & $\bullet$ & $\bullet$ & $\Delta$ & $\bullet$ & $\bullet$ & $\bullet$ & \\
\hline $\begin{array}{l}\text { Thorncliffe Neighbourhood } \\
\text { Office }\end{array}$ & Multicultural NGO & $\bullet$ & $\bullet$ & $\bullet$ & $\bullet$ & $\bullet$ & & $\bullet$ \\
\hline$*$ COSTI & Universal Service Provider & $\bullet$ & $\bullet$ & & $\bullet$ & $\bullet$ & & \\
\hline YWCA & Universal Service Provider & & $\bullet$ & & & $\bullet$ & $\bullet$ & \\
\hline
\end{tabular}

\footnotetext{
${ }^{3}$ - represents general coverage on one or more job seeking needs/activities for each basic employability dimension and other languages $\Delta$ represents indirect access to job boards/postings

* Assessment based solely on information obtained online
} 


\subsection{Content: Type of Labour Market Information}

When examining the sources and context of information relayed on four basic employability dimensions, the nature of LMI provision remains highly fragmented. Not all providers at a pre and post arrival stage cover all four basic employability dimensions. The only provider covering all basic employability dimensions is OCASI's Settlement.org and Inmylanguage.org. Even with the LMI covered on certain dimensions, there is limited coverage to inform/support one or all activities recent immigrants may be interested in undertaking during job seeking process. The most fragmentation on the quality and quantity of LMI available for all job seekers, including recent immigrants, was on the following dimensions:

Career decision making information should inform/support the selection of a potential occupation(s), setting criteria for alternative choices in occupations, establishing priorities and/or preferences in terms of career choice, and researching and exploring different career options (White Mountain Consulting, n.d; Amundson, 2003). The degree of coverage on activities varied by providers in both pre and post arrival samples.

- Government providers and initiatives provided the greatest quantity and quality of coverage on career decision making online. The main federal government site, WorkInCanada.ca highlighted select occupations which coincide with current immigration selection and labour market priorities. E.g. Under Federal Skilled Worker programs is a list of eligible occupations related to skilled trades and select few for professional/technical services occupations. However, the opportunity to research and explore any occupations and gain a detailed labour market supply/demand outlook was made available on JobBank.gc.ca. Among specific partnership initiatives a different quality 
LMI on to inform career decision making was reflected in the career maps and fact sheets developed with industry partners $(G E O)$ and alternative career pathways developed by Settlement.org $(C I I P)$. Finally, to complement all LMI general welcome guides include information guides/booklets outlining general steps how to finding work, eg, Welcome to Canada, What you should know, or steps to finding work or getting accredited in specific occupations (GEO career maps)

- Education and Training providers provided the least coverage on career decision making. Information obtained from pre-arrival sample directly support or inform priorities and/or preference in terms of career choices emphasized definitions for regulated versus non-regulated professions.

- Industry and Regulatory Bodies only focused on establishing priorities for registration process with Colleges outlined by regulated laws and policies. Mainly after certification or re-training has been completed with certified education and training bodies.

- Non-governmental Organizations typically offer a large quantity of flyers, leaflets and material on local skills enhancement programs covering various entry and middle level service based occupations. With the exceptions of government prepared guide-books and resources provided by ISAs, eg. Welcome in Canada, What you should know, there is not information on skills enhancement material to support activities under career decision making. Especially on labour market supply and demand outlooks, essential or transferrable skills needed, thus making it less useful for establishing commensurate or alternative career priorities or preferences. 
There was some consistency on the type of LMI available for all job seekers, including recent immigrants was on the following dimensions:

- Skills enhancement information should inform the generic and specific occupation skills/competencies required for performing an occupation(s) (White Mountain Consulting, n.d; Amundson, 2013). This was the most covered employability dimension by all providers. At a pre arrival stage, Government of Canada, Federal-Provincial Partnerships, Education and Training bodies focused on outlining key literacy \& numeracy skills and occupational requirements needed as per National Occupational Classification. Upon arrival, an even larger quantity of information on literacy \& numeracy skills training programs was remitted by in-person. Very little information provided insight on interpersonal skills and self-management skills needed for performing certain occupation(s). It can mainly be obtained from Settlement.org and Inmylanguage.org. And Multicultural NGOs with a thematic focus immigrant employment (i.e. ACCES Employment).

- Job Search information typically includes job search techniques, eg. resume, writing and access to job boards/postings largely consisted of links to relevant government and industry-based sites. Job bank website was featured on all elven selected online sources, with two websites featuring the new widget tool for in-site job hunting (Global Experience Ontario and Work In Canada). However, other smaller job hunting databases are also available online and in-print (local classified newspapers) from localized government and NGO providers. Overall, very little is available to assist when or how to use specific job search techniques. The only exceptions are OCASI's, Settlement.org and Inmylanguage.org and career development books/toolkits for read-only in some government and multicultural NGO resources centres (TESS-High Park/Parkdale, Centre de Francophone Toronto). 
- Employment maintenance information on maintaining stable employment or having personal control/stability during unemployment and job search was the least covered employability dimension. Particularly at a pre arrival stage, where only 3 of 11 selected online sources covered this topic, namely OCASI's settlement.org, inmylanguage.org, and City of Toronto, Immigration Portal. Information largely included eligibility for employment and social service benefits, a breakdown of basic employment rights, and where to obtain localized support in the City of Toronto. At a post arrival stage, there was greater quantity of coverage by 10 of 14 selected sources in-person. However, it was just more of the same information remitted by online sources.

\subsection{Source and Context of LMI Provision}

\section{Credibility}

A variety of sources were consulted and/or recommended in LMI obtained from both pre and post arrival samples. While the amount varied, there is some consistency in the types of sources and geographic scope referenced from LMI obtained. Federal government, Federal-Provincial Partnership (CIIP), Provincial government, and Education and Training providers typically relay or refer LMI on career decision making, skills enhancement and job search information from government, education and training and industry providers. LMI relayed on these dimensions are predominately situated on national scale. This commonly includes specific credential assessment tools from national industry and education bodies, and general career decision making and access job search via Jobbank.gc.ca. There was some diversity in scope of LMI from Provincial (Global Experience Ontario) and Federal-Provincial Partnership (CIIP) which reflect multi-stakeholder engagement with education and training bodies on bridge-to-work programs and universal service provision from "focal point partners" like COSTI immigrant services (CIIP, 2014, Murphy, 2014). As well, new technological improvements to 
JobBank.gc.ca (Drummond, 2014) provide brief updates on changes in local business and hiring patterns occurring in different regions, cities and towns across Canada, which impact current demand for certain occupations.

In contrast, localized providers typically recommend a range of LMI on programs available to support skills enhancement, job searching, and employment maintenance from all levels of government in addition to local education and training and NGO providers. Most tips and tools on skills enhancement and job searching provided referrals to programs delivered by local education and training and NGO providers. Specific employment and social benefits programs to support employment maintenance drew from Provincial and Municipal government, City of Toronto (immigration e-portals and TESS).

Consulting or recommending a number of external LMI sources was undertaken by Immigrant Servicing Agencies (ISAs) who typically provide more settlement information on housing, education, money and finances, healthcare or citizenship. Therefore most employment information/resources available from ISAs were often prepared by other community-based or government providers. Interestingly, the only resources ISAs had to guide career decision making or to generally make sense of LMI for job hunting process was government-based. Namely, Federal and Provincial government booklets entitled "Welcome to Canada, What you should know", "Planning to Work in Canada", and "Welcome to Ontario". The provision LMI from multiple sources was also not an uncommon practice among Universal Service Providers, Multicultural, and Issue-based NGOs. In fact, it reflects the referral process undertaken by Toronto's non-profit sector in order to cater to unique/intersecting needs of job seeker(s) on a 'needs-based', 'specialization-based' or 'case management' model previously recommended by George (2002). 


\section{Location and Timing}

LMI collected from both samples generally satisfied the basic needs in life-course transitions adult immigrants with a family typically need information, service and support in the pre-migration and settlement phase, outlined by Kunz (2005:53, Figure 2). At a pre arrival stage, all eleven selected sources were accessible to prospective immigrants to engage with online, with the exception of CIIP satellite offices in China, India, Philippines and UK and in-person services upon arrival from Education and Training bodies (World Education Services and Canadian Information Centre for International Credentials).

In comparison, time and location impacted accessibility of LMI available at post arrival stage. More information was publically available in-person through resource centres and even more can be obtained on need basis through one-on-one consultations with employment counsellors, which was outside the scope and ethical parameters of this study. The timing of this study during summer, JuneJuly 2014, impacted my ability to collect information from all sources and provide accurate assessment on what is typically available year round. For one, I was unable collect all publicly available in-person from Toronto Catholic District School Board, Eglinton East location, which was closed until September 2014; and COSTI, Ralph Chiodo Immigrant Reception Centre, had no open access to its resource Centre and required an appointment with the program manager. Second, the collection of resources was only conducted once which makes it hard to determine how up-to-date or reliable the LMI may or may not be. Community-based and government-based employment programs advertised in leaflets/pamphlets are always subject to change (Shields and Richmond, 2004).

When examining the consistency online, the same general information flyers/pamphlets on inhouse program were available to collect in-person. Very few had more detailed information available 
online that is useful for both pre and post arrival stages. These include more information to support all four employability dimensions. Namely from Toronto Employment and Social Services via Employment Opportunities System and City of Toronto, Immigration Portal; COSTI Immigrant via Online workshops and live chat; and Frequently asked questions discussing job search techniques, live chat, agency job board postings from ACCES employment.

\subsection{Target of Message}

It was difficult to accurately measure for who the content was intended to target and the perceived similarities to recent immigrants within the scope of this study. Unless directly stated by selected providers, most content/documents can be relevant for any or all groups. Eg. Job bank is noted as tool/resource for anyone seeking employment in Canada. Only select providers or tools i.e. CIIP, RoutestoEmployment.ca and RoutetoTrades.ca who clearly state LMI are designed to help Internationally Educated Professionals.

Every job seeker has unique needs/purposes for seeking and utilizing general settlement information and/or 'problem specific' information, i.e. employment (Esses and Medianu, 2012; Caidi, Allard, Quirke, 2010). Their information practices are further compounded by different ethno-cultural communication abilities (Hall 2000 quoted in Esses and Medianu, 2012) not to mention plans to seek work in Canada depend on individual life course status are contingent on temporary or permanent immigration streams they are eligible and have been accepted under. These include the Canadian Experience Class, Federal Skilled Worker Programs (Type 0, Levels A \& B) or Provincial Nominee Programs. Therefore, the sources, context, content, and format of LMI present different levels of cognitive complexity and relatability for individual job seekers and even broadly among specific job 
seeker groups, ie. low-skilled and highly skilled foreign trained persons. Only two sub-factors examined in this content analysis provide preliminary insight on degree of perceived similarity to recent immigrants. These are languages used to deliver LMI and testimonials from recent immigrants and immigrants using available labour market information, tips, and tools.

\section{Language(s)}

LMI is mainly relayed in English and/or French. The provision of LMI in other languages remains limited online and in-person, with only some certified translation on select documents that can be utilized by recent immigrants coming from source countries with "high-context cultures". These include some languages spoken by larger populations of South Asians, Chinese, Black, Filipino, Korean, Arab and Japanese minorities residing across Toronto (City of Toronto, 2013: 5).

- English only: At a pre arrival stage, 3 of 11 selected online sources were provided in English only. Specifically, World Education Services, City of Toronto-Immigration Portal and RoutestoTrades.ca. At a post arrival stage, 6 of 14 selected sources were provided in English only. Specifically, Education and training, industry, one ISA, i.e Heritage skills Development Centre, and one universal service provider, COSTI.

- English and French: At a pre arrival stage, 8 of 11 selected online sources provided LMI in English and French Translation. These included government providers or funded settlement intiatives, eg. Work In Canada, Job Bank, CIIP, Global Experience Ontario, Inmylanaguage.org, Settlement.org, and Routestoemployment.ca. At a post arrival stage, there is less LMI translated in Canada's official languages. Namely, Centre Francophone de Toronto, an issued based Multicultural NGO serving francophone persons, and YWCA (website translation). 
- Other languages: Very few providers relay LMI in languages used by recent immigrants and certified translations was limited to select documents.

- In the pre arrival sample, 3 of 11 selected online sources provide LMI in other languages. Global Experience Ontario provides multilingual certified translation for the general career decision making guide, "Work in Your Profession" in Arabic, Chinese, Farsi, Tagalong, Greek, Hindi, Italian, Korean, Polish, Portuguese, Punjabi, Russian, Spanish, Tamil, and Urdu. Similarly, OCASI's Settlement.org and Inmylanguage.org provides certified translations in Arabic, Chinese, Gujarati, Tagalog, Punjabi, Russian, Spanish, Tamil and Urdu. Translations included topics related job maintenance, eg. statutory employment rights.

- In contrast, 6 of 14 post arrival providers sampled only had certified translations for basic program information that included employment support. This was largely obtained in-person from TESS locations (materials from specific ISAs offering satellite location services), Immigrant Servicing Agencies and one Multicultural NGO, Thorncliffe Neighborhood office.

- Non-certified translations: Other means of multilingual translation was uncovered online. Few organizations added a google translate widget feature to e-portals in an attempt to relay information to wider audience. The exceptions were the Canadian Information Centre for International Credentials and ACCES Employment. 


\section{Testimonials}

There are few testimonials about obtaining and utilizing pre and post arrival employment information, services and support from formal providers in Canada's labour force development system. Only select initiatives based online and funded in partnership with the Federal Government featured successful outcomes of newcomers who utilized community-based or government funded programs. These include a video testimonials from CIIP clients, service providers, and industry partners; YouTube series on newcomer experiences of finding 'Alternative Work' developed by OCASI's settlement.org; and small written testimonials of newcomers in professional technical services and skilled trades on routestoemployment.ca and routestotrades.ca. In comparison, even smaller amounts of testimonials about challenges and opportunities associated with specific activities concerning basic employability dimensions can be obtained in-person. ACCES Employment was the only NGO with testimonials of newcomers utilizing programs prominently on flyers for literacy, numeracy and occupational skills training and job hunting services. Other means of obtaining testimonials can also be obtained through the most recent issues of local immigrant magazines, Canadian Immigrant and Canada Bound Immigrants. Copies of these magazines were obtained from Toronto Employment and Social Services and Multicultural NGOs.

\section{ANALYSIS}

Based on the persuasive communication factors examined, it is clear the nature of LMI provision in Canada's labour force development system remains inconsistent with some key principals of social inclusion necessary for supporting and advancing the economic integration of immigrants (Omidvar and Richmond, 2003). There is an overwhelming amount of LMI available in Canada's labour force 
development system which does not clearly cover all basic employability dimensions. This leaves the most newly acquainted labour market participants, recent immigrants, unable to independently make realistic, informative and suitable employment choices needed to more effectively integrate in the Canadian labour market.

\section{Valued recognition}

The limited amount of LMI translated in other languages does not recognize the linguistic diversity among new immigrants living, working and/or studying across major global or 'gateway' cities and regions across Canada, like Toronto. Based on the literature review, Canada's linguistic diversity has significantly increased with the recent influx of new immigrants from Philippines, South Asia, East Asia and West Asia between 2006 and 2011 Statistics Canada, 2011a;2011b). At a local level, this linguistic diversity is reflected in the top ten mother tongue and home languages spoken among various communities (City of Toronto, 2014b) ${ }^{4}$. With the exception of certified translations on general service pamphlets/flyers in languages catering to specific immigrant populations in NGO and TESS service catchment area, there are no other post arrival resources from local education and training and industry providers translated to reflect Toronto and more broadly, Canada's linguistic diversity. First, this limits recent immigrants to certified translations on select activities concerning career decision making, skills enhancement, job search and job maintenance provided via Settlement.org, Inmylanugage.org, as well as, the general LMI career decision making guide, "Working in my Profession", created by Global

\footnotetext{
${ }^{4}$ City of Toronto, 2014b, Ward Profiles provide social demographics for 14 selected sources in post arrival sample. Specifically, Etobicoke North, Ward 2; High Park, Ward 14; Scarborough Southwest, Ward, 36; Trinity Spadina Ward 20 \&21;Scarbourough Centre, Ward 38; Don Valley West, Ward, 26; Don Valley East; Ward 33; St. Paul's , Ward 22; Rosedale, Ward 27; Scarborough Centre, Ward 38.
} 
Experience Ontario. Second, English and/or French only formatting of LMI may present particular difficulties' for recent immigrants with little to no oral /written proficiencies' in either of Canada's national languages. This leaves them dependent on translations services from family, friends or language interpreter services provided by community or government based providers. There is no research to determine where newcomers are likely to go for interpretation and what impact the interpretation from family, friends or formal interpretation services has on influencing newcomers' clarity about and utility of LMI in job hunting process. However, research on transnational immigrant information and communication practices confirms informal sources of LMI provision/support via ethno-linguistic gatekeepers and ICTs are preferred by recent immigrants (Caidi, Allard and Quirke, 2010; Kelly, 2003). Therefore whatever quantity and quality of information transmitted in mother tongue or home language is likely to garner more trust, reliability, and therein impact how recent immigrants make sense and utilize formal LMI.

\section{Human development and Material well-being}

Skills enhancement is the most covered content by all providers with the larger quantities available in-person from NGO providers at a post arrival stage. The excessive emphasis on quantity not quality in skills enhancement information provision only seeks to reinforce market demands for 'credentialism'. The excessive quantities are not surprising given the demands government and employers/industry leaders make on 'quality' human capital to advance Canada's economic grow (Reitz 2007; Galabuzi, 2006; Teelucksingh and Galabuzi, 2007). These demands are conventional arguments made by employers and governments to reinforce 'credentialism', emphasis on excessive diplomas, degrees, or professional licenses to qualify for hiring or promotion. This phenomenon has only created 
more barriers in the recruitment, selection and retention processes in a wide range of occupations not limited to highly skilled, eg. retail management and administration. More importantly, this has become the driving factor fueling education-based competition among labour market participants, especially among recent immigrants whose foreign skills, talents, and capacities are often not recognized as high ‘quality'.

Unfortunately, labour market studies measuring years of education conclude returns on retraining has too often not wagered better employment outcomes for immigrants, instead the incomeearning gaps between immigrants compared to Canadian-born has only widened since 1980s (Reitz, 2007; Galabuzi, 2006; Teelucksingh and Galabuzi, 2007). Skills enhancement programs may not be the only issues attributed for the "brain waste" immigrants experience when their educational attainment and experience do not translate into commensurate occupational status and income (Galabuzi, 2006: 136). It has been linked to employer attitudes in the recruitment and selection process as well as institutional processes in settlement and employment programming (Teelucksingh and Galabuzi, 2007). These include a lack of adequate and reliable information/tools about licensing process and credential assessment, pre and post arrival; inadequate bridge to work and other education training programs which do not provide work place/internship opportunities to gain 'Canadian experience'; limited transparency and feedback in the licensing process; and limited coordination between stakeholders (ibid). Many of these issues require policy-oriented interventions, which are continually addressed at inter-governmental, sectorial and NGO policy/practitioner forums by leading settlement actors in Toronto, namely, the Maytree Foundation and OCASI (Biles et. al, 2011; Stasiulus, Hughes and Amery, 2011). While some progress has been made, especially on post arrival employment and settlement programming, this content analysis uncovers that 
there is still insufficient consideration given on informational issues concerning the credential assessment and re- accreditation process, pre and post arrival.

First, the content collected in-person barely relays any occupational or industry specific outlooks to verify the relevance and value of training programs to meet labour market demands. However, there are occupational or industry specific outlooks provided online via jobbank.gc.ca, globalexperienceontario.ca, routestoemployment.ca, routestotrades.ca. But only some NGO providers had materials available informing job seekers about accessing jobbank.gc.ca and/or globalexperienceontario.ca tools for further information. The absence of labour market supply/demand information available in-person can be partly attributed to issues with data collection, interpretation, and dissemination in Canada's labour force development system. In particular, Drummond (2014) notes there are mixed and evolving views on labour market supply/demand outlooks particularly from government and industry based sources, which make it difficult to interpret whether information on anticipated Canadian workforce shortages in certain occupations are precisely true or false, eg. skilled trades. For NGO providers working with limited money, time or human resources, undertaking quantitative and/or qualitative research to assess official labour market or census datasets is an impossible task (TIEDI, 2012b). Evidently, this was the major impetus which prompted the establishment of communityuniversity research alliances in Toronto to fill the noticeable LMI data provision gap, ie. the Toronto Immigrant Employment Data Initiative (TIEDI, 2012a; 2012b). However, these reasons alone should not exempt localized providers, especially NGOs across Ontario from integrating more local labour market supply/demand LMI from all available online sources. Especially, LMI from local workforce planning boards, whose information collection draws from multiple stakeholders in education, labour, business, municipal government (TWIG, 2013); and are among the few sources in Canada's labour force 
development system interpreted from a worker-based perspective (Advisory Panel on Labour Market Information, 2009).

Second, it largely excludes the basic employability skills Canadian employers and industry stakeholders cite as important to enter, stay, and progress in the Canadian workforce (Conference Board of Canada, 2014). These include fundamental skills, ie. communication, information management, numeracy and analytical; personal management skills ( eg., positive attitudes, responsibility, adaptability, continued learning, health and safety); and team work skills (ibid). With the exception of ACCES Employment, a Multicultural NGO specializing in employment, most NGO providers had very general program information on flyers which included eligibility requirements, program schedule, and sometimes included key learning components. The same type of content was conveyed in other flyers/pamphlets/booklets prepared by local universities, colleges and private career training institutions.

\section{Involvement and Engagement}

The absence of an LMI guide, checklist or toolkit to navigate websites and/or resource centers can make process of working through a highly fragmented LMI system extremely overwhelming. This is concerning given that various career and information guides are already complied by key players in Canada's labour force development system. These include guides, checklists or toolkits specifically to help newcomers/or any job seeker with the process of finding employment and career mapping in specific occupations or included in sections of general settlement guides. The resources below were identified through the collection and assessment of this content analysis. In terms of format, the guides largely varied in size and scope, from small checklists (eg OCASI's First Days Guide); to medium sized 
documents covering steps to accreditation in selection occupations (eg. GEO); and even large books as read only resources for career development. The following is a list of these resources:

General newcomer settlement guides containing employment guides/checklists: "Welcome to Canada, What you should know" by CIC; "First Days Guide: A Newcomer's Guide to Their First Two weeks in Ontario", by Settlement.Org; "Welcome to Ontario, A Guide to Programs and Services for Newcomers to Ontario", by Ontario Ministry of Citizenship and Immigration; and Canadian Newcomer Series: Arrival Survival Canada: A Handbook for New Immigrants by Nick Noorani and Sabrina Noorani.

Specific employment guides tailored for newcomers include: "Planning to Work in Canada? An essential workbook for newcomers" by CIC Foreign Credentials Referral Office; "Work in Your Profession”, Ontario Ministry of Citizenship and Immigration; Canadian Newcomer Series: How to Find a Job in Canada by Efim Chenis and Dale Sproule; "9 soft skills No Immigrant Should be Without: A Practical Guide for Newcomers Entering the Canadian Labour Market", by Nick Noorani, Prepare for Canada.

Specific career mapping guides for selection occupations for newcomers from Global Experience Ontario covering: 15 non-health regulated occupations, eg, Accounting, Architecture, Engineering; 24 Regulated Health occupations, eg. Audiology/Speech, Chiropody, Chiropractic, Dental, Medical Lab technicians; 12 other professions, eg, Business, Finance and Insurance Management; 22 Mandatory skilled trades eg. Electrician; and 12 non-mandatory, eg. Automotive services, construction, hairstylists.

Specific career development and job hunting resources complied by Canadian career development specialists, eg. Best Canadian Cover Letters, $2^{\text {nd }}$ Edition by Sharon Graham 
One LMI guide available for all job seekers in Ontario, “Guide to Using Labour Market Information in Ontario" complied by Ontario Ministry of Training, College and Universities.

Guides are necessary since the nature of LMI provision within Canada's labour force development system is demonstrated to be highly fragmented and hard for anyone to navigate, unless assisted by someone highly familiar (Advisory Panel on Labour Market Information, 2009). Even with use of structured coding sheet and relying on my local workforce development experience, I encountered difficulties with collecting LMI. There were no LMI guides recommended or contained in content collected online and in-person, except from government based documents from GEO and TESS, universal service providers, ie. OCASI, and ISAs, i.e. University Settlement, KWCA Family Services. This is likely to increase the difficulties recent immigrants, or for any other newly acquainted labour market participants seeking when collecting and making sense of available LMI from labour force development providers.

Increasing the provision of LMI guides currently available, however, may not necessarily help recent immigrants make better sense of how to obtain and use information to support employment and settlement in Canada, given that immigrants tend to seek and obtain information on any major domain of life and work by happenstance (Caidi, Allard, Quirke, 2010). Instead, emphasis should be placed on ensuring the quality and format of employment guides made available can help recent immigrants make the right and necessary decisions to support themselves, families and communities. The only sources offering structured guides with multilingual translation are OCASI's Settlement.org and Inmylanauge.org; and GEO, career maps and general LMI guide, "Work in Your Profession". Only some general information pamphlets from localized providers recommended these online resources, while 
more comprehensive government-based employment and settlement guides are available from ISAs. Government-based employment guides are basic steps in worksheet format outlining how to undertake for initial labour market integration and also includes information on other key domains of life newcomers typically need to support and assist re-settlement for themselves and families (Esses and Medianu, 2012). The types of information and format of government-based guides do not provide the same quality of information complied by more structured and multilingual resource guides on full realties of employment and settlement services provided by OCASI's settlement.org. Nor does it provide occupational-specific career mapping guides complied by GEO. These can inherently leave many unanswered questions about the realities and challenges on finding work in select occupations, which are important factors newcomers need to prepare themselves and the family for mitigating the challenges of job hunting in the short-term and long-term.

The small number of LMI guides available from government sources are clearly intended to provide basic introductory support/information, while more 'needs based', 'specialization-based' and 'case management' service provision during intake engages is designed to meet the unique and intersecting needs of immigrant job seekers (George, 2002). The parameters of this study prevents closer examination of LMI provision and guidance during in-take, and thus makes it hard to critically assess what type of guidance is provided, the specific LMI guides used by providers and jobseekers, and its impact on how immigrants make sense and utilize LMI in job hunting. However, discussions with Canadian settlement and career practitioners reveal there are issues with employment services provided by non-profit sector which can impact the labour market outcomes of immigrants and other jobseekers. Across Ontario's city regions of Toronto, Ottawa, Peel, Niagara and Waterloo, the current contract funding model has significantly added pressure on settlement service providers to meet high service 
quotas with diminishing resources (Stasilus, Hughes and Amery, 2011). The movements to a so-called "efficient" servicing and information referral model (ibid) has resulted in a system where the emphasis has been placed on getting clients jobs but issues of retention and skills commensurate employment are sacrificed. Additionally, the individual knowledge and capacities of employment counselors/job developers/career and information workforce specialists significantly shape the types of labour market information, supports and services jobseekers require (Occhiuto and Quintero, 2012; Redekopp, Hopkins and Hiebert, 2013). This reality suggest that more consideration is needed to ensure the type and format of guidance, whether online or in person, is in place to effectively help immigrants and any other jobseeker find employment.

\section{CONCLUSION AND RECOMMENDATIONS}

For prospective and recent immigrants seeking information to support or inform job hunting process in the Canadian labour market, there is an overwhelming quantity of information made available by formal providers. However, the nature of LMI provision remains highly fragmented with varied coverage on four basic employability dimensions: career decision making; skills enhancement; job search; and employment maintenance. The informational issues uncovered in formal labour market information provision in Canada's labour force development system reinforce some issues raised by policy makers and practitioners about the absence of good, reliable, timely and accessible labour market information for all labour market participants, which includes immigrants and service providers (Advisory Panel on Labour Market Information, 2009; Drummond, 2014; Sharpe and Qiao, 2006). More specifically, at a local level in major metropolitan cities, like Toronto, where many newcomers are settling and competing 
with other jobseekers for available work opportunities (City of Toronto, 2013; 2014; Tal and Enenajor, 2013), there is a need for excellent and accessible LMI services.

Through a closer examination of LMI obtained online and in-person from all levels of government, education training bodies, industry and regulated bodies and NGOs, my content analysis identified specific informational issues concerning the quantity and quality of sources, context, content and format at a pre and post arrival stage. Combined it presents a fragmented system of information provision which falls short of meeting the basic employability dimensions and largely inhibits the most newly acquainted labour market participants, recent immigrants, from independently making realistic, informative, and suitable employment choices needed to effectively integrate in the Canadian labour market. This significantly contributes to the consistent confusion, unrealistic job seeking expectations, and ineffective skills matching attributed to the unfulfilled needs required to meet Canada's changing economy and local labour markets (Advisory Panel on Labour Market Information, 2009; Drummond, 2014; Criptoph, 2003), as well as failing to value and make use of foreign skills, capacities, talents and experiences immigrants have to offer Canada (Galabuzi, 2006).

There are number of policy-based and practitioner-based interventions in need of immediate interventions to ensure recent immigrants seeking work are equipped with the information, tips, and tools needed to mitigate or alleviate barriers preventing access and mobility in the Canadian labour market. Many of these echo recommendation already made by Advisory Panel for Labour Market Information (2009), Drummond (2014), TIEDI (2012b) and the Toronto Workforce Planning Board (TWIG, 2013).

First, more localized labour market information/data needs to be collected, interpreted and disseminated in official census data sets specifying outcomes of particular groups in the Canadian labour market, especially on the basis of education, gender, experience, immigration status, and a variety of other 
workplace and employment factors (Advisory Panel on Labour Market Information, 2009;TIEDI, 2012b). As well as, there should be better tracking of newcomers and other job seeker usage and their employment outcomes from employment program services including bridge to work training programs and OW services provided by a number of localized providers to monitor and prevent overlap and other information and servicing inefficiencies (TWIG, 2013:30). This can greatly improve the quality of LMI available for NGO providers, which they can utilize and incorporate into information and resources designed and delivered for recent immigrants pre and post arrival. On a similar but different note, I would argue there are already large amounts of localized labour market available for newcomers seeking work in Ontario, Toronto and the Greater Toronto Area to access from GEO, City of Toronto, Immigration Portal and Toronto Workforce Innovation. Yet a small level of engagement and recommendation of these localized sources is observed in the nature of LMI provision from National and Provincial level labour force actors, particularly government. More initiative to integrate and recommend more localized LMI from Federal and Provincial government providers should be undertaken, especially given that they fund many localized LMI projects and tools.

Second, the highly fragmented nature of LMI provision in Canada's labour force development system often duplicates information and therefore needs more coordination among actors (Advisory Panel on Labour Market Information, 2009; Drummond, 2014). Some efforts to centralize information have already started among the Government of Canada with converging WorkinginCanada.gc.ca tool into JobBank.gc.ca (Drummond, 2014). In addition, this study uncovered a free online widget was developed for Jobbank.gc.ca and shared on the websites of other government based sources (eg. GEO). Adding this widget on other website allows users to enhance LMI search and provides direct links to main portal. The practice of sharing Jobbank.gc.ca widget should be adopted by all other providers, especially education 
and training, industry and regulated bodies and NGO providers. Additionally, the web-based development of e-portal widgets from leading employment and settlement in major regions and cities across Canada, like Ontario and Toronto (eg. OCASI's settlement.org and Inmylanguage.org) that is attached to the websites of other formal LMI providers can add to centralization efforts currently undertaking to reduce overwhelming amount and highly fragmented LMI systems. As well as, ensuring newcomers are receiving more localized, structured and multilingual LMI provision.

Third, to ensure more reliable, timely and accessible LMI provision for newcomers and all job seekers, each provider should make it a practice to regularly review and adhere to the Career and Labour Market Information, Service Delivery Guide, developed by the Forum of Labour market Ministers, Labour Market Information Working Group (2012). This guideline provides basic steps to ensure LMI provision considers seven main areas: 1) Service delivery environment, 2) Funding, 3) Determining target group needs, 4) Delivery methods, 5) Staffing, 6) Marketing and Communication, and 7) Use of Technology. The use of this guideline will point service providers, in particular, to address provision gaps concerning linguistic diversity of newcomers to Canada.

This guideline alone, however, is not enough to address the specific LMI service delivery issues found in the Ontario and Toronto's settlement Sector. Nor can it holistically address the specific LMI gaps on four basic employability dimensions that are identified above and often missing but needed by jobseekers in employment and which support career and workforce specialists provide (OCASILearnATWork, 2014; Amundson, 2003; Redekopp, Hopkins and Hiebert, 2013; White Mountain Counsulting,n.d.). A new or more comprehensively revised LMI guide needs to be developed in consultation with career and information specialist training. This needs to be accompanied with enhanced services facilitated by leaders in LMI services. In Toronto, these mainly include TWIG, TESS, ONE 
STEP, OCASI's LearnatWork and ACCES Employment. Discussions should include a focused conversation on developing a basic LMI package with key types of resources and content to ensure more consistency in LMI available from local government, education training and NGO providers.

\section{Areas for Further Research}

The informational perspective on how immigrants obtain and make sense of labour market information to find employment is largely an under-examined issue.(Caidi, Allard and Quirke, 2010). Even less has been done to understand what impact LMI has on employment outcomes of many job seekers in Canada (Murray, 2010). The factors examined in this small-scale qualitative content analysis cannot conclusively determine how and to what degree the sources, context, content and format of LMI provided influences how recent immigrants obtain and make sense about how to find and take advantage of Canadian workforce opportunities. More qualitative and quantitative research is needed to directly engage and solicit the experiences of recent immigrants about how they obtained and used LMI to find and maintain employment in Canada. This can include obtaining and utilizing information from more informal sources, eg. ethno-linguistic gatekeepers and ICTs found in newcomer communities (Caidi, Allard, and Quirke, 2010; Kelly, 2003). Additionally, exploring other factors related to the job search model of high and low skilled immigrants noted by Guerrero and Rothstein is needed (2012:326, Figure 3). For example, job seeking behaviours, which are independent factors outside LMI provision and which are also central in shaping employment outcomes should be factored more centrally into t labour market analysis. 


\section{Appendix 1. Pre Arrival LMI Provision Sample}

\begin{tabular}{|c|c|c|}
\hline Source & Type of Provider & Location (online) \\
\hline Work in Canada & Federal Government & $\begin{array}{l}\text { http://www.cic.gc.ca/enGlIsH/ } \\
\text { work/index.asp }\end{array}$ \\
\hline $\begin{array}{l}\text { Job Bank } \\
\text { (formerly Working in Canada, } \\
\text { HRSDC) }\end{array}$ & Federal Government & $\begin{array}{l}\text { http://www.jobbank.gc.ca/home } \\
\text {-eng.do?lang=eng }\end{array}$ \\
\hline $\begin{array}{l}\text { Canadian Immigrant Integration } \\
\text { Program (CIIP) }\end{array}$ & Federal-Provincial Partnership & $\begin{array}{l}\text { http://www.newcomersuccess.c } \\
\text { a/index.php/en/about-ciip }\end{array}$ \\
\hline Global Experience Ontario (GEO) & Provincial Government & $\begin{array}{l}\text { http://www.ontarioimmigration. } \\
\mathrm{ca} / \mathrm{OI} / \mathrm{en} / \mathrm{geo} / \mathrm{index} . \mathrm{htm}\end{array}$ \\
\hline $\begin{array}{l}\text { City of Toronto, Immigration } \\
\text { Portal }\end{array}$ & Municipal Government & $\begin{array}{l}\text { http://www1.toronto.ca/wps/por } \\
\text { tal/contentonly?vgnextoid=6fa6 } \\
\text { ba2ae8b1e310VgnVCM100000 } \\
\text { 71d60f89RCRD }\end{array}$ \\
\hline Routes TO. Employment & $\begin{array}{l}\text { Local workforce planning } \\
\text { board }\end{array}$ & http://routestoemployment.ca/ \\
\hline Routes TO. Trades & $\begin{array}{l}\text { Local workforce planning } \\
\text { board }\end{array}$ & http://www.routestotrades.ca/ \\
\hline World Education Services & Education and Training & https://www.wes.org/ca \\
\hline $\begin{array}{l}\text { Canadian Information Centre for } \\
\text { International Credentials (CICIC) }\end{array}$ & Education and Training & http://cicic.ca/ \\
\hline Settlement AtWork.org & $\begin{array}{l}\text { Universal Service Provider, } \\
\text { NGO }\end{array}$ & $\begin{array}{l}\text { http://www.settlement.org/inde } \\
\text { x.asp }\end{array}$ \\
\hline Inmylanguage.org & $\begin{array}{l}\text { Universal Service Provider, } \\
\text { NGO }\end{array}$ & $\begin{array}{l}\text { http://www.inmylanguage.org/i } \\
\text { ndex_en.html }\end{array}$ \\
\hline
\end{tabular}

${ }^{5}$ Special cases/initiatives available as of April 2014 
Appendix 2. Post Arrival LMI Provision Sample ${ }^{6}$

\begin{tabular}{|l|l|l|}
\hline Source & Type of Provider & Location (in-person) \\
\hline $\begin{array}{l}\text { Toronto District School Board } \\
\text { (TDSB) }\end{array}$ & Education and Training & 515 Consumers Rd \\
\hline $\begin{array}{l}\text { Toronto Catholic District } \\
\text { School Board (TCDSB) }\end{array}$ & Education and Training & 90 Eglinton Ave E. \\
\hline $\begin{array}{l}\text { College of Dental } \\
\text { Technologists of Ontario }\end{array}$ & Industry and Regulatory Body & 2100 Ellesmere Rd \\
\hline $\begin{array}{l}\text { College of Midwives of } \\
\text { Ontario }\end{array}$ & Industry and Regulatory Body & 21 St. Clair Ave East \\
\hline $\begin{array}{l}\text { Toronto Employment and } \\
\text { Social Services (TESS)- } \\
\text { Attwell }\end{array}$ & Municipal Government & 200 Attwell Drive \\
\hline $\begin{array}{l}\text { Toronto Employment and } \\
\text { Social Services (TESS)- } \\
\text { Parkdale/High Park }\end{array}$ & Municipal Government & 1900 Dundas St. West \\
\hline $\begin{array}{l}\text { Heritage Skills Development } \\
\text { Centre }\end{array}$ & $\begin{array}{l}\text { Immigrant Serving Agency } \\
\text { (ISA), NGO }\end{array}$ & 400 McCowan Rd \\
\hline $\begin{array}{l}\text { University Settlement, } \\
\text { Spadina Office }\end{array}$ & $\begin{array}{l}\text { Immigrant Serving Agency } \\
\text { (ISA), NGO }\end{array}$ & 720 Spadina Ave \\
\hline $\begin{array}{l}\text { KCWA Family and Social } \\
\text { Services }\end{array}$ & Issued-based, NGO & 27 Madison Ave \\
\hline $\begin{array}{l}\text { ACCES Employment- } \\
\text { Scarbourough }\end{array}$ & Issued-based, NGO & 2100 Ellesmere Rd \\
\hline $\begin{array}{l}\text { Centre Francophone de } \\
\text { Toronto }\end{array}$ & Multicultural NGO & 2 Carlton St. \\
\hline $\begin{array}{l}\text { Thorncliffe Neighbourhood } \\
\text { Office }\end{array}$ & Multicultural NGO & 18 Thorncliffe Park Dr \\
\hline $\begin{array}{l}\text { *COSTI, Ralph Chiodo } \\
\text { Family Immigrant Reception } \\
\text { Centre }\end{array}$ & $\begin{array}{l}\text { Universal Service Provider, } \\
\text { NGO }\end{array}$ & 100 Lippincott St. \\
\hline $\begin{array}{l}\text { YWCA } \\
\text { NGO }\end{array}$ & 87 Elm Street \\
\hline
\end{tabular}

${ }^{6}$ Based on providers listed in Employmentontario.ca and 211Toronto.ca service directories as of July 2014 


\section{Appendix 3.LMI Content Analysis Selective Coding Guide}

\section{i. Source and Context of Information Provision}

$>$ Credibility (types of provider)

○ Industry and Regulatory Bodies

○ Government (Federal, Provincial, Municipal)

○ Non-governmental Organization

- Education \& Training

- Labour

○ Other:

$>$ Perceived similarity to the Target (recent immigrants)

- Oral or written testimonials from immigrants

$>$ Location/Venue

○ Online

$\circ$ In-person

○ Both

$>$ Timing $^{7}$

○ Pre-arrival

- Adaptation

- Settlement

$\circ$ Integration

${ }^{7}$ Based on four major phases Adult immigrant settlement trajectory in Canada identified by Kunz (2005:53, Figure 2) 


\section{ii. Content and Format of Message}

Type of Labour Market Information ${ }^{8}$

\begin{tabular}{|c|c|}
\hline Four Basic Employability Dimensions & Specific Job seeking activities \\
\hline 1)Career Decision Making & 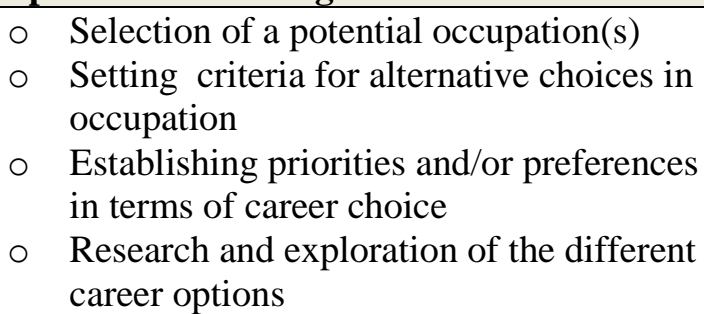 \\
\hline 2) Skills Enhancement & $\begin{array}{ll}\text { ○ } & \text { Interpersonal skills } \\
\circ & \text { Self-management skills } \\
\circ & \text { Literacy \& Numeracy skills } \\
\circ & \text { Occupational skills }\end{array}$ \\
\hline 3) Job Search & $\begin{array}{l}\text { Job search techniques (ie. resume, } \\
\text { writing, using LMI, networking and } \\
\text { employment contact skills) } \\
\text { Access to Job boards/postings }\end{array}$ \\
\hline 4) Job Maintenance & $\begin{array}{l}\text { Coping strategies for personal } \\
\text { stability/life during unemployment and } \\
\text { job search }\end{array}$ \\
\hline
\end{tabular}

Language(s)

$\circ$ English

- French

○ Other:

\footnotetext{
${ }^{8}$ Based on benchmarks outlined by Career Development and Settlement Practioners (see OCASI-LearnAtWork, 2014; Amundson, 2003; Redekopp, Hopkins and Hiebert, 2013; White Mountain Consulting, n.d)
} 


\section{iii. Target of Message}

$>$ Source Country and Culture ${ }^{9}$

○ "High context culture"- recent immigrants coming from Asia, South Asia, West Asia countries since $1980 \mathrm{~s}$

- "Low context culture"- older waves of immigrants from Eastern and Southern European Countries prior 1960s

$>$ Immigration Class

- Economic Class

- Family Class

- Refugee class

Geographic location in Canada (for newcomers living, working or studying )

○ Toronto

- Specific catchment area:

- Greater Toronto Area

○ Ontario

${ }^{9}$ Based on Stuart Hall's (2000) discussion on different cultural communication abilities (quoted in Esses and Medianu, 2012) 


\section{REFERENCES}

Advisory Panel on Labour Market Information (2009). Working Together to Build a Better Labour Market Information System for Canada, Final Report. Ottawa: Human Resource and Skills Development Canada. Retrieved from http://publications.gc.ca/collections/collection_2011/rhdcc-hrsdc/HS18-24-2009-eng.pdf

Akter, N., Ropkara-Sarsu, S., Dyson, D. (2013). Shadow Economies: Economic Survival Strategies of Toronto Immigrant Communities. Toronto: Wellesley Institute. Retrieved from http://www.wellesleyinstitute.com/wpcontent/uploads/2013/10/Shadow-

Economies-FINAL.pdf

Aizlewood, A. \& Pendakur, R. (2004). Ethnicity and Social Capital in Canada. Research on Immigration and Integration, Working Paper Series, No.04-09. Vancouver Centre for Excellence: Research on Immigration and Integration.

Amundson, N.(2003). Career Development: Employability Dimensions. Canadian Career Development Foundation: Ottawa. Retrieved from http://sks.karabuk.edu.tr/kariyer/belgeler/CAREER_DEVELOPMENT.pdf

Bauder, H. (2006) Labor Movement: How Migration Regulates Labor Markets. New York: Oxford University Press, pp. 19-34.

Biles, J., Tolley, E., Andrew, C., Esses, V. and Burstein, M. (2011). Integration and Inclusion in Ontario: The Sleeping Giant Stirs. In J.Biles, M. Burnstein, J. Frideres, E. Tolley and R. Vineberg (eds.), integration and Inclusion of Newcomers and Minorities across Canada, (195246).

Block, S. \& Galabuzi, G. (2011). Canada's Colour Coded Labour Market: The Gap for racialized workers. Wellesley Institute: Toronto

Caidi, N. \& Allard, D. (2005). Social inclusion of newcomers to Canada: An information problem? Library and Information Science Research (27)3: 302-324.

Caidi, N. Allard, D.\& Quirke, L.(2010). The Information Practices of Immigrants. Annual Review of Information Science and Technology (ARIST), 44: 493-531

CIIP(2014a). Canadian Immigrant Integration Program: Partners for Newcomer Success. Retrieved from http://www.newcomersuccess.ca/index.php/en/about-ciip 
-----(2014b). Canadian Immigration Integration Program (CIIP) Quarterly Statistical Report, October 1, 2010- March 31, 2014. Retrieved from http://www.newcomersuccess.ca/images/stories/reports/2014-march-stats-report.pdf

City of Toronto (2013). 2011 National Household Survey: Immigration, Citizenship, Place of Birth, Ethnicity, Visible Minorities, Religion and Aboriginal Peoples. City of Toronto, Backgrounder. Retrieved from http://www.toronto.ca/demographics/pdf/nhs_backgrounder.pdf

Retrieved from http://www1.toronto.ca/City\%20Of\%20Toronto/City\%20Planning/SIPA/Files/pdf/S/survey2013. pdf

(2014b). Demographics: Ward Profiles. Toronto: City of Toronto, Living in Toronto Retrieved from http://www1.toronto.ca/wps/portal/contentonly?vgnextoid=9d2254bcd2012410VgnVCM100000 71d60f89RCRD

Critoph, U. (2003). Toronto Labour Force Readiness Plan: An Integrated Labour Force Development System for Toronto. Retrieved from https://www1.toronto.ca/static_files/economic_development_and_culture/docs/labour_force_syst em_screen.pdf

Drummond, D. (2014). Wanted: Good Canadian Labour Market Information. IRPP Insight 6 (June 2014). Montreal: Institute for Research on Public Policy. Retrieved from http://irpp.org/wpcontent/uploads/2014/06/insight-no6.pdf

Elo, S. \& Kyngäs.(2008) The qualitative content analysis process. Journal of Advanced Nursing 62(1), 107-115.

Esses, V. \& Medianu, S.(2012) Integration and Information as a Solution: Report Based on literature covering 2005-2011 Inclusive. Citizenship and Immigration Canada: Integration Branch. http://p2pcanada.ca/wp-content/uploads/2012/08/Integration-Barriers-and-Infomation-asa-Solution.pdf 
Fang, T., Damsbaek, N., Kelly, P., Lemoine, M., Lo, L., Preston, V., Shields, J., Tufts, S. (2010). Are Immigrant Wages Affected By The Source Of Job Search Information?. TIEDI Analytical Report 7. Retrieved from http://www.yorku.ca/tiedi/doc/AnalyticalReport7.pdf

Galabuzi (2006). Canada's Creeping Economic Apartheid: The social exclusion of racialised groups in the New century. Toronto: Canadian Scholars Press

George, U. (2002). A needs-based model for settlement service delivery for newcomers to Canada. International Social Work, 45(4), 465-480

Guerrero, L. \& Rothstein, M. (2012). Antecedents of Underemployment: Job Search of Skilled Immigrants in Canada. Applied Psychology: An International Review, 61 (2), 323-346 doi: 10.1111/j.1464-0597.2011.00470.x

Kelly, P. (2003). Canadian-Asian Transnationalism. The Canadian Geographer, 47(3), 209- 218.

Kunz, J. (2005). Orienting newcomers to Canadian society: Social capital and settlement. In Social Capital in Action: Thematic Policy Studies (52-64). Ottawa: Policy Research Initiative.

Labour Market Information Working Group (2012). Career and Labour Market Information: Service Delivery Guidelines. Forum of Labour Market Minsters, Labour Market Information Group. Retrieved from http://www.flmm-lmi.org/CMFiles/Publications/whatnew/LMI-ServiceGuidelines-ENG-2.02.pdf

Lo, L. , Wang,L., Wang, S. \& Yuan, Y. (2007). Immigrant Settlement Services in the Toronto CMA: A GIS-Assisted Analysis of Supply and Demand. CERIS Working Paper, 59, 1-64. http://www.ceris.metropolis.net/wpcontent/uploads/pdf/research_publication/working_papers/wp 59.pdf

Lo, L., Wang, S, Anisef, P., Preston, V. \& Basu, R. (2010). Recent Immigrants' Awareness of, Access to, Use of, and Satisfaction with Settlement Services in York Region. CERIS Working Paper, 79, 1-42. http://www.ceris.metropolis.net/wpcontent/uploads/pdf/research_publication/working_papers/wp79.pdf

Murphy, C. (2014). The Immigrant Continuum: Supporting Immigrants from Invitation to Integration, Canadian Immigrant Integration Program. Plenary Session 5 presentation at the Canadian Immigration Conference 2014: Enhancing Canada's Immigration System-from Invitation to Integration, Toronto, ON. 
Murray, A. (2010). The State of Knowledge on the Role and Impact of Labour Market Information: A Survey of the Canadian Evidence. Ottawa: Centre for the Study of Living Standards. Retrieved from http://www.csls.ca/reports/csls2010-04.pdf

OCASI-LearnAtWork. (2014). Using Employability Dimensions for a Basic Employment Needs Assessment. Ontario Council of Agencies Servicing Immigrants (OCASI) Employment ServicesA Training for Settlement Workers.

Occhiuto, L. \& Quintero, M. (2012). Enhancing Labour Market Information for Ontario's Employment Services Sector. Toronto: Toronto Workforce Innovation Group (Unpublished Report).

Ooka, E. \& Wellman, B. (2003). Does Social Capital Pay off more within or between ethnic Groups? Analyzing Job Searches in Five Toronto Ethnic groups. Toronto: University of Toronto Press.

Preston, V., Damsbaek, N., Kelly, P., Lemoine, M., Lo, L., Shields, J., Tufts, S. (2010). What Are The Labour Market Outcomes For University-Educated Immigrants?. TIEDI Analytical Report 8. Retrieved from http://www.yorku.ca/tiedi/doc/AnalyticalReport8.pdf

Qadeer, M. (1999). The Bases of Chinese and South Asian Merchants' Entrepreneurship and Ethnic Enclaves, Toronto, Canada. CERIS Working Paper No.9. Toronto: Joint Centre of Excellence for Research on Immigration and Settlement. Retrieved from http://ceris.metropolis.net/Virtual\%20Library/economic/QADEER_CWP9.pdf

Omidvar, R. \& Richmond. T.(2003), Immigrant Settlement and Social Inclusion in Canada. Laidlaw Foundation, Working Paper Series: Perspectives on Social Inclusion.

Redekopp, D., Hopkins, S. \& Hiebert, B. (2013). Assessing the Impact of Career Development Resources and Practitioner Support across the Employability Dimensions. Canadian Career Development Foundation: Ottawa. Retrieved from http://www.ccdf.ca/ccdf/wpcontent/uploads/2013/07/Employability-Dimensions-Report-2013-5-30-FINAL-CCDF.pdf

Reitz, J. (2007) Immigrant Employment Success in Canada, Part I and II. Journal of International Migration and Integration 8: 11-62 
Richmond, T. \& Shields, J. (2004). Third Sector Restructuring and the New Contracting Regime: The Case of Immigrant Serving Agencies in Ontario. Centre for Voluntary Sector Studies, Working Paper Series, 24, 1-27. http://www.ryerson.ca/cvss/files/WP24COVER.pdf

Sassen, S. (2001). The Global City: New York, London, Tokyo. Oxford: Princeton University Press

Sharpe, A. \& Qiao, S. (2006). The Role of Labour Market Information for Adjustment:

International Comparisons. Ottawa: Centre for the Study of Living Standards. Retrieved from http://www.csls.ca/reports/csls2006-03.pdf

Shields, J., Kelly, P., Muranaghan, A.M., Park, S., Lemoine, M. (2011). What Kind Of Tests Are Required For Immigrants To Get Hired?. TIEDI Analytical Report 19 . Retrieved from http://www.yorku.ca/tiedi/doc/AnalyticalReport19.pdf

Shields, J., Lo, L., Zikic, J., Atlin, J. (2011). Access and Entry to the Labour Market: Entry Barriers and the Job Search Process. TIEDI Research Snapshot 2. Retrieved from http://www.yorku.ca/tiedi/doc/snapshot2.pdf

Statistics Canada. (2011a). Linguistic Characteristics of Canadians: Language, 2011 Census of Population. Statistics Canada,. Catalogue no. 98-314-X2011001.

(2011b). Table 1. Population of immigrant mother tongue families, showing main languages comprising each family, Canada, 2011. Statistics Canada. Retrieved from http://www12.statcan.gc.ca/census-recensement/2011/as-sa/98-314-x/2011003/tbl/tbl3_2-1-eng.cf

Stasiulis, D. Hughes, C, Amery, Z. (2011). From Government to Multilevel Governance of Immigrant Settlement in Ontario's City-regions. In E. Tolley and R. Young (eds.) Immigrant Settlement Policy in Canadian Municipalities, 73-147.

Tal, B. \& Enenajor, E. (26 Aug 2013). Degrees of Success: The Payoff to Higher Education in Canada. CIBC Economics: In Focus. Retrieved from http://research.cibcwm.com/economic_public/download/if_2013-0826.pdf 
Teddlie, C. \& Yu, F. (2007). Mixed Methods Sampling: A Typology with Examples. Journal of Mixed Methods Research (1)1, 77-100

Teelucksingh, C \& Galabuzi, G. (2007). Working Precariously: The impact of Race and Immigrant Status on Employment Opportunities and Outcomes in Canada. In T. Das Gupta, C. James, P. Maaka, Galabuzi, G., C.Anderson(eds.), Race and Racialization: Essential Readings, 202-209.

TIEDI (2012a). Toronto Immigrant Employment Data Initiative. Retrieved from http://www.yorku.ca/tiedi/tiedi.html

TIEDI (2012b). Filling the Data Gap: A Conversation on Coordinating and Using Program Data. TIEDI Roundtable Discussion Paper \# 2. Retrieved from http://www.yorku.ca/tiedi/doc/Roundtable2d.pdf

TWIG (2011). Sifting Through the Sands: Unpacking the Hourglass. Toronto: Toronto Workforce Innovation Group. Retrieved from http://www.workforceinnovation.ca/sites/default/files/SiftingThroughTheSandsWeb.pdf

TWIG (2013). Toronto's Opportunities and Priorities: Local Labor Market Update 2013. Toronto Workforce Innovation Group. Retrieved from http://www.workforceinnovation.ca/sites/default/files/TOP2013_WebVersion_1.pdf

Wilkinson, D. \& Birmingham, P. (2003). Using Research Instruments: A Guide for Researchers. London: RoutledgeFalmer.

White Mountain Consulting (n.d.). The Four Employability Dimensions. Retrieved from http://www.nwac.ca/files/6-The\%20Four\%20Employability\%20Dimentions.pdf

Xue, L. (2008). Social Capital and Employment Entry of Recent Immigrants to Canada: Evidence from the Longitudinal Survey of Immigrants to Canada (LSIC). Retrieved http://www.cic.gc.ca/english/pdf/research-stats/social-capital-w3-eng.pdf 